\title{
Tunisia: 2009 Article IV Consultation-Staff Report; and Public Information Notice
}

In the context of the 2009 Article IV Consultation, the following documents have been released and are included in this package:

- $\quad$ The Staff Report for the 2009 Article IV Consultation, prepared by a staff team of the IMF, following discussions that ended on June 9, 2008, with the officials of Tunisia on economic developments and policies. Based on information available at the time of these discussions, the staff report was completed on July 24, 2009. The views expressed in the staff report are those of the staff team and do not necessarily reflect the views of the Executive Board of the IMF.

- A public Information Notice.

The policy of publication of staff reports and other documents allows for the deletion of market-sensitive information.

To assist the IMF in evaluating the publication policy, reader comments are invited and may be sent by e-mail to Publicationpolicy@imf.org.

Copies of this report are available to the public from

International Monetary Fund • Publication Services

$70019^{\text {th }}$ Street, N.W. • Washington, D.C. 20431

Telephone: (202) 623-7430 • Telefax: (202) 623-7201

E-mail: publications@imf.org Internet: http://www.imf.org

Price: $\$ 18.00$ a copy

\section{International Monetary Fund}

Washington, D.C. 


\section{INTERNATIONAL MONETARY FUND}

\section{TUNISIA}

\section{Staff Report for the 2009 Article IV Consultation}

Prepared by the Staff Representatives for the 2009 Consultation with Tunisia

Approved by Amor Tahari and Dominique Desruelle

July 30, 2009

Discussions took place during June 10-24, 2009 in Tunis. The mission comprised Mr. Toujas-Bernaté (head) and Ms. Simard (both MCD), Ms. Valderrama (INS), and Mr. Bayle (Banque de France expert). Mr. Tahari (MCD) and Mr. Rouai (OED) participated in the discussions.

The mission met with Governor Baccar, Minister of Finance Kechiche, Minister of Economic Development and International Cooperation Jouini; the ministers of agriculture, industry, tourism and social affairs, and other government officials; and private sector and labor representatives.

Tunisia continues its close dialogue with the Fund while retaining full ownership of its economic program. The previous consultation was concluded on August 6, 2008. The staff report and PIN are available at http://www.imf.org/external/country/TUN/index.htm

The de facto exchange rate regime will be reclassified from "conventional peg to a composite" to "floating."

Tunisia accepted the obligations of Article VIII, sections 2, 3, and 4 in 1993. It subscribed to SDDS in June 2001. The timeliness and coverage of macroeconomic data are generally adequate for surveillance.

Tunisia has consistently published all documents related to the Article IV consultations. Outreach activities included a meeting with parliamentarians; a presentation by Mr. Tahari of MCD's Regional Economic Outlook to the media and at a conference of the Union of Maghreb Banks; and an interview and a press release at the end of the mission. 


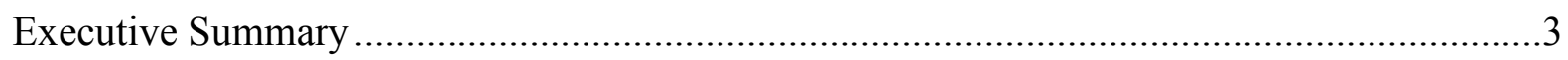

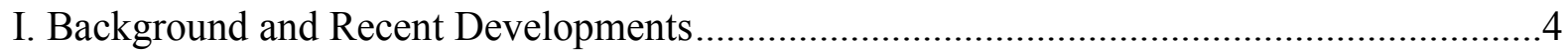

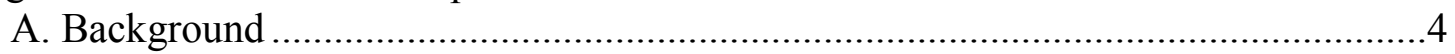

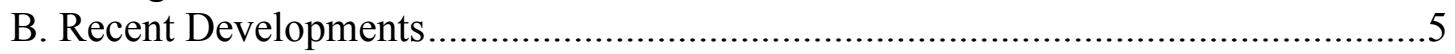

II. Outlook and Risks ...........................................................................................

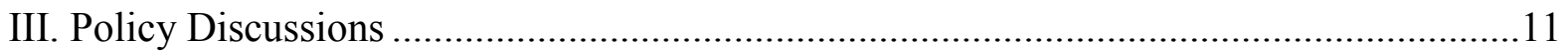

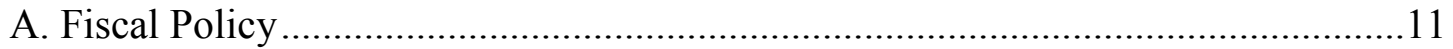

B. Monetary and Exchange Rate Policy ............................................................ 14

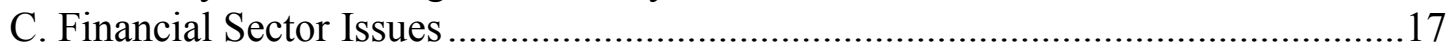

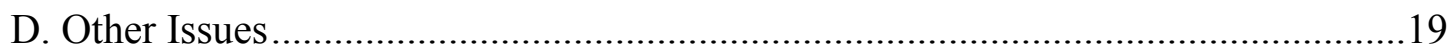

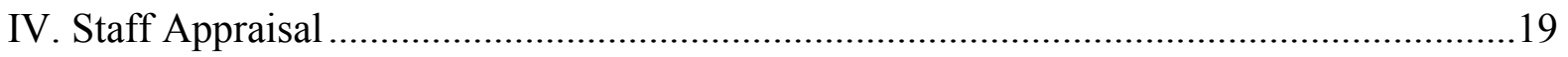

Boxes

1. Limited Exposure to Financial Contagion ................................................................. 10

2. The 2009 Supplementary Budget and Fiscal Stimulus Package.......................................14

3. An Assessment of the Exchange Rate Level ............................................................... 16

Figures

Panel A. Exports Fell and Real GDP Growth Slowed Down But Reserve Remain Comfortable ........................................................................................... 7

Panel B. Credit to the Economy Is Buoyant and the Stock Market Resilient...........................8

1. External Debt Sustainability: Bound Tests ..................................................................29

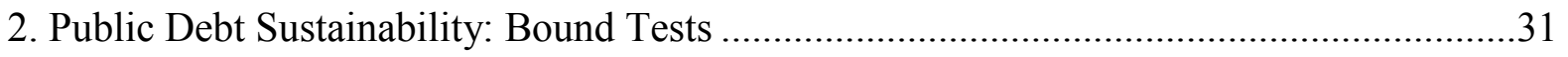

Tables

1. Selected Economic and Financial Indicators, 2006-14 _............................................22

2. Balance of Payments, 2006 -14 ..........................................................................................23

3. Central Government Financial Operations, 2006-14 ..................................................24

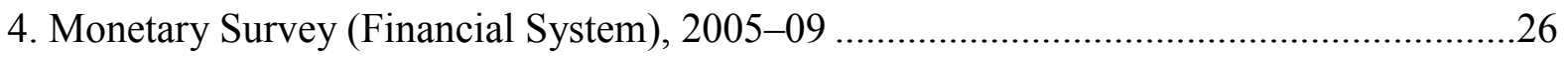

5. Illustrative Medium-Term Growth Scenario, 2006-14 ..............................................27

6. External Debt Sustainability Framework, 2004-14 ..................................................28

7. Public Sector Debt Sustainability Framework, 2004-14 ..................................................30

\section{Annexes}

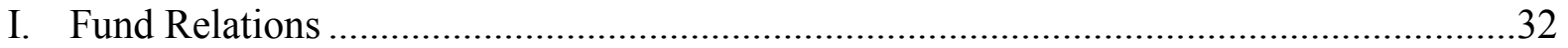

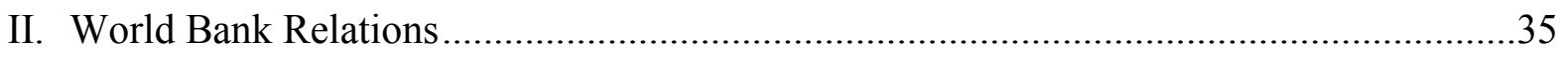

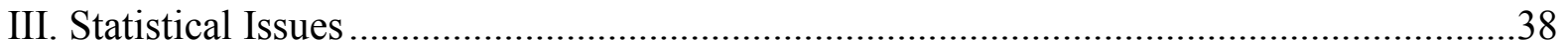




\section{EXECUTIVE SUMMARY}

\section{Background}

Sound economic policies and structural reforms underpinned by increasing trade openness allowed Tunisia to record higher growth in recent years and strengthen its footing to face the current global crisis. Tunisia's immediate challenge is to mitigate the adverse impact of a depressed external demand. Over the medium term, its main objective remains to reduce the still relatively high unemployment rate. Although affected by the crisis mainly through falling exports, Tunisia is weathering its impact relatively well, thanks to resilient remittances and tourism receipts. Growth may reach 3 percent this year if the fiscal stimulus swiftly impacts demand. Discussions focused on short-term macroeconomic policies to support demand while preserving medium-term financial sustainability, and reforms for productivity gains.

\section{Authorities' views}

- $\quad$ Fiscal prudence remains a key priority of the authorities, but they will implement a fiscal stimulus package given the exceptionally depressed external environment. They will reevaluate it for 2010, considering a deficit target of 3.8 percent of GDP as an upper bound. They are resolutely committed to reverting to medium-term fiscal consolidation as soon as growth firms up.

- $\quad$ The authorities stand ready to further ease monetary policy to sustain demand if necessary. They reaffirmed their objective of a freely floating exchange rate over the medium term.

- The authorities have taken steps to strengthen the banking sector and recognize the need for further progress. In the context of the transition towards Basel II, they agree that a more prospective approach to risk management is required.

\section{Staff recommendations}

The staff broadly supports the authorities' macroeconomic policy stance and encourages them to continue implementing reforms to enhance the economy's resilience and improve growth and employment. In particular:

- $\quad$ The targeting of expenditure should be refined to free up more resources for fiscal stimulus in 2010 and accelerate fiscal consolidation over the medium term.

- $\quad$ Further adjustments in monetary policy should be gradual, in order to preserve its credibility, particularly in a context of rising world prices as the recovery takes hold.

- $\quad$ Continued strengthening of the banking sector is needed, and it would be desirable to systematize and formalize stress tests to better assess its potential vulnerabilities. 


\section{BACKGROUND AND RECENT DEVELOPMENTS}

\section{A. Background}

1. Sound economic policies and structural reforms, underpinned by increasing trade openness, allowed Tunisia to record higher growth and strengthen its footing to face the current global crisis. Over the last decade, growth averaged 5 percent, real GDP per capita increased by 46 percent, inflation was maintained at 3 percent on average, the public debt-to-GDP ratio declined by 9 percentage points to $471 / 2$ percent of GDP, and reserves increased from $2 \frac{1}{3}$ to 5 months of imports. The Association Agreement with the European Union (EU), signed in 1995, was instrumental in raising trade openness and inducing productivity gains by exposing the industrial sector to global competition. Tunisia's prudent macroeconomic policies and structural reforms have improved its resilience to economic slowdowns with lower public and external indebtedness and much higher reserves coverage of short-term external debt.

Episodes of Economic Slowdown: 2002 and 2009

Selected Indicators

\begin{tabular}{|c|c|c|c|c|c|c|}
\hline & 2001 & 2002 & 2003 & 2008 & 2009 & 2010 \\
\hline & \multicolumn{6}{|c|}{ (In percent) } \\
\hline Real GDP growth & 5.0 & 1.7 & 5.6 & 4.6 & 3.0 & 4.0 \\
\hline \multirow[t]{2}{*}{ CPI inflation (average) } & 1.9 & 2.7 & 2.7 & 5.0 & 3.5 & 3.4 \\
\hline & \multicolumn{6}{|c|}{ (In percent of GDP) } \\
\hline Central government balance $1 /$ & -3.8 & -3.5 & -3.4 & -1.2 & -3.8 & -3.8 \\
\hline General government debt & 62.7 & 61.5 & 60.5 & 47.5 & 48.7 & 49.0 \\
\hline External debt & 66.5 & 67.5 & 66.8 & 53.7 & 52.5 & 52.3 \\
\hline \multicolumn{7}{|l|}{ Gross official reserves } \\
\hline In months of next year's imports of goods and services & 2.4 & 2.5 & 2.5 & 4.9 & 5.1 & 5.5 \\
\hline \multirow[t]{2}{*}{ In percent of short-term debt at remaining maturity } & 55.0 & 58.9 & 61.8 & 150.3 & 171.2 & 173.7 \\
\hline & \multicolumn{6}{|c|}{ (In percent of total loans) } \\
\hline Nonperforming loans & 21.0 & 21.4 & 23.6 & 15.5 & $\ldots$ & $\ldots$ \\
\hline
\end{tabular}

Source: Tunisian authorities; and IMF staff estimates.

$1 /$ Excluding grants and privatization

\section{In the current severely deteriorated international environment, Tunisia's} immediate challenge is to mitigate the adverse impact of a depressed external demand. It is highly dependent on European countries for exports, tourism receipts, remittances and FDI inflows. These countries are experiencing the worst recession in sixty years and their activity is projected to strengthen more slowly than elsewhere. Thanks to its prudent policies in the past, Tunisia has room for short-term expansionary fiscal and monetary policies to sustain demand. 
Main Links Between Tunisia and the European Union, 2008

Exports of goods
(47 percent of GDP)

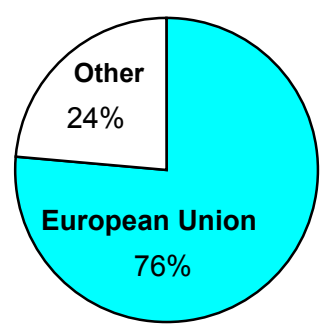

Remittances

(5 percent of GDP)

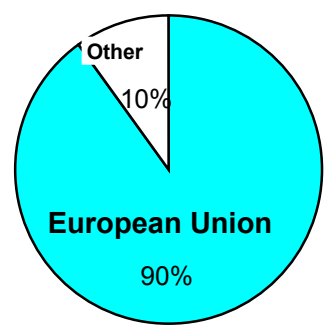

Tourism

(7 percent of GDP)

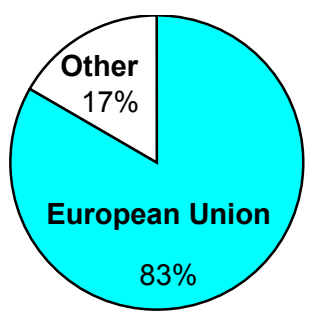

FDI inflows

(6 percent of GDP)

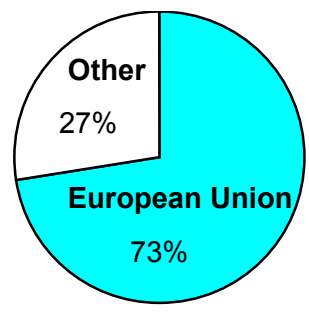

Sources: Tunisian authorities; and IMF staff estimates.

3. Over the medium term, Tunisia's main challenge remains to reduce the still relatively high unemployment rate, particularly among young university graduates. Bringing unemployment down from 14.2 percent in 2008 to the authorities' objective of 10 percent by 2016 will require sustaining a 6 percent annual growth for several years. This will necessitate continued structural reforms aimed at additional productivity gains, including through further integration in the regional and global economies. Tunisia's resilience to shocks will be enhanced through prudent macroeconomic policies and further strengthening of its financial sector.

\section{B. Recent Developments}

4. Although affected by the global crisis, Tunisia is weathering its impact relatively well. Exports fell but resilient receipts from tourism and remittances have so far contributed to maintaining a comfortable level of reserves.

- $\quad$ Real GDP growth slowed down from an average of 4.6 percent in 2008 to 0.5 percent (year-on-year) in the first quarter of 2009, reflecting mainly a fall in exports of manufactured goods to EU countries. This drop was partially offset by buoyant growth in the mining and energy sectors and in some services. Domestic demand was sustained by investment and strong consumption fueled by salary increases. $^{1}$

- Inflation declined from an average of 5 percent in 2008 to $3 \frac{1}{2}$ percent (year-onyear) in June 2009 due to the fall in global food and fuel prices and an appropriate

\footnotetext{
${ }^{1}$ As part of the 2008 triennial agreements, salaries were raised by $4.2-5.5$ percent for private sector employees, 4 percent in public enterprises, and 4.7 percent for civil servants.
} 
monetary policy, while price increases for other services accelerated slightly, in line with rising salaries.

\section{The current account deficit, after widening in 2008, contracted in the first}

quarter of 2009. Increases in imports of raw materials and capital brought the current account deficit to 4.2 percent of GDP in 2008. With lower import prices contributing to an improved trade balance and resilient tourism and remittances receipts, the deficit declined in early 2009. Despite somewhat smaller foreign investments inflows in early 2009, the external position remains comfortable with reserves at US $\$ 9$ billion at end-May 2009 (5.6 months of projected imports).
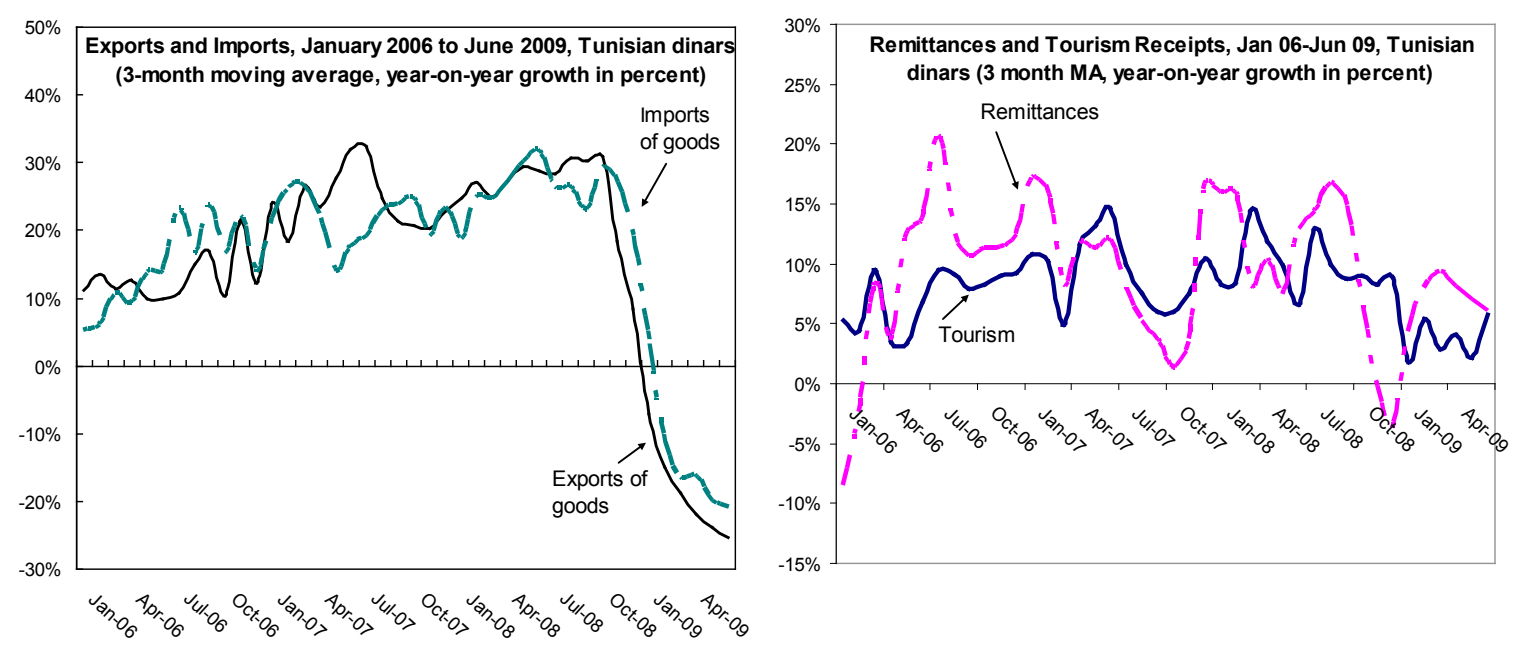

Source: Tunisian authorities; and IMF staff estimates.

- The fiscal deficit declined markedly in 2008 to 1.2 percent of GDP and the public debt-to-GDP ratio was further reduced. Revenue increased by over 2 percentage points of GDP from 2007, boosted by buoyant customs duties levied on higher priced imports and strong corporate income tax receipts from high 2007 profits. Combined with lower interest payments, this more than offset expenditure overruns on subsidies for staple foods and petroleum products due to higher world prices. With this fiscal consolidation, the public debt-to-GDP ratio declined from 50 percent in 2007 to $471 / 2$ percent in 2008. In January-April 2009, the continued good revenue performance and lower subsidies offset the wage bill increase.

- $\quad$ The Central Bank of Tunisia (BCT) reacted to the economic slowdown by loosening its monetary policy in 2009. After raising it twice in 2008, the BCT lowered its required reserves ratio from 10 percent to 7.5 percent at end-2008. It also reduced its key policy rate from 51/4 percent to $4 \frac{1}{2}$ percent in February 2009, its first such policy change in thirty months. Meanwhile, the BCT almost continuously absorbed the abundant liquidity in the banking system mainly due to Treasury operations and foreign reserves inflows. In the year to May 2009, the nominal 
Panel A. Exports fell and real GDP growth slowed down but reserves remain comfortable...
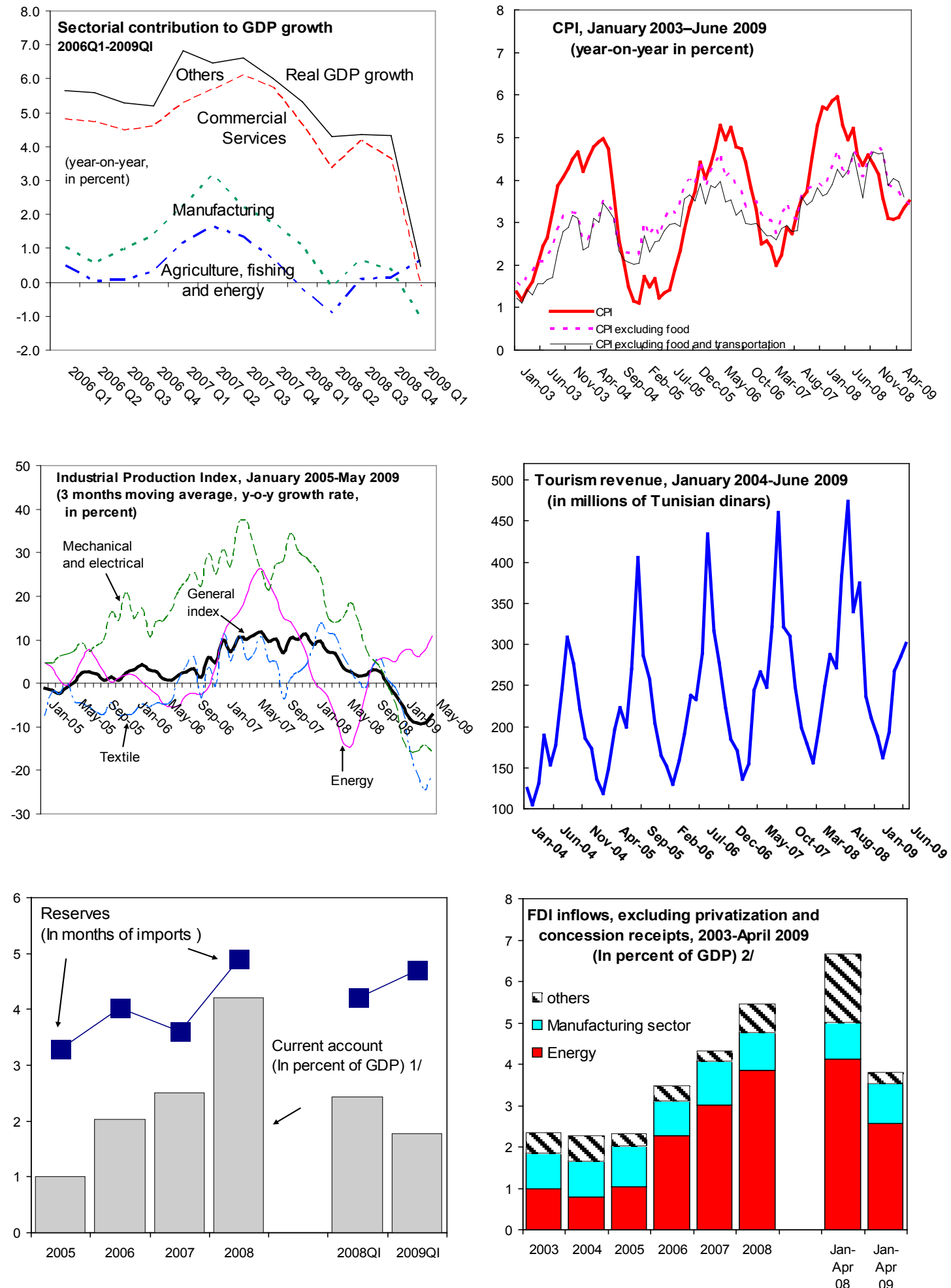

1/ The ratio for the first quarter is annualized, IMF projections for 2009.

2/ The ratio for January-April is annualized, IMF projections for 2009. 
Panel B. ...Credit to the economy is buoyant and the stock market resilient.
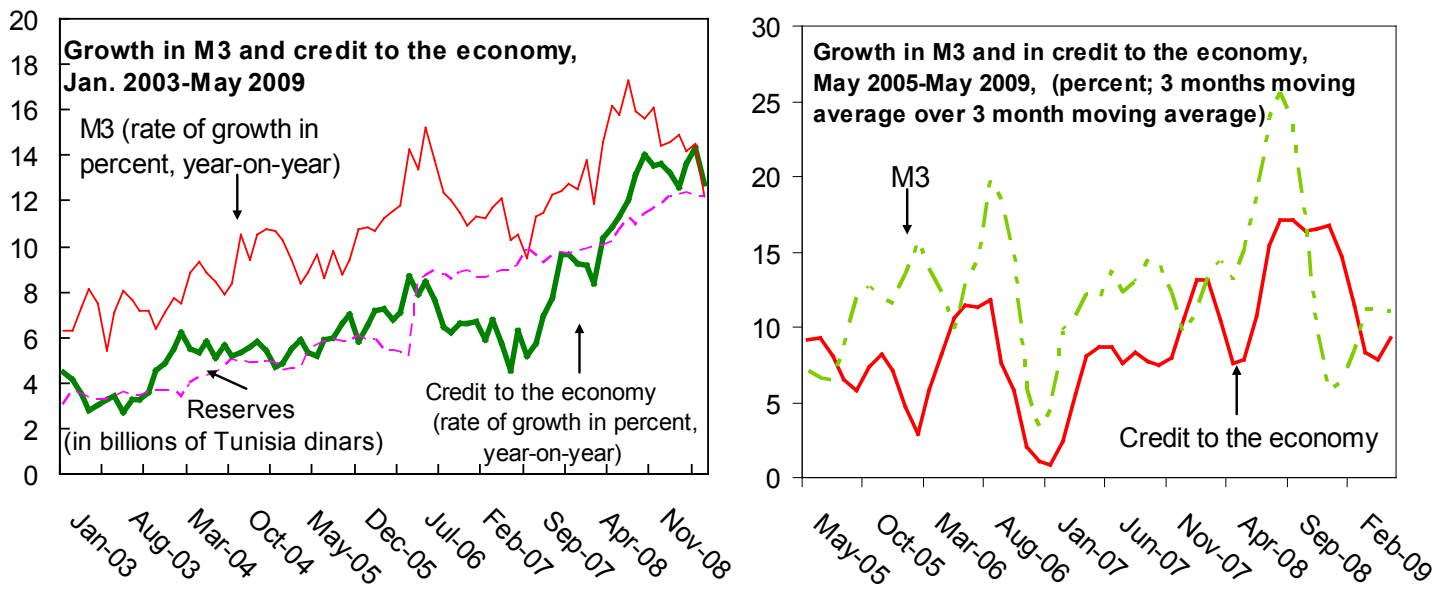

Credit by sector of activity, in billions of Tunisian dinars
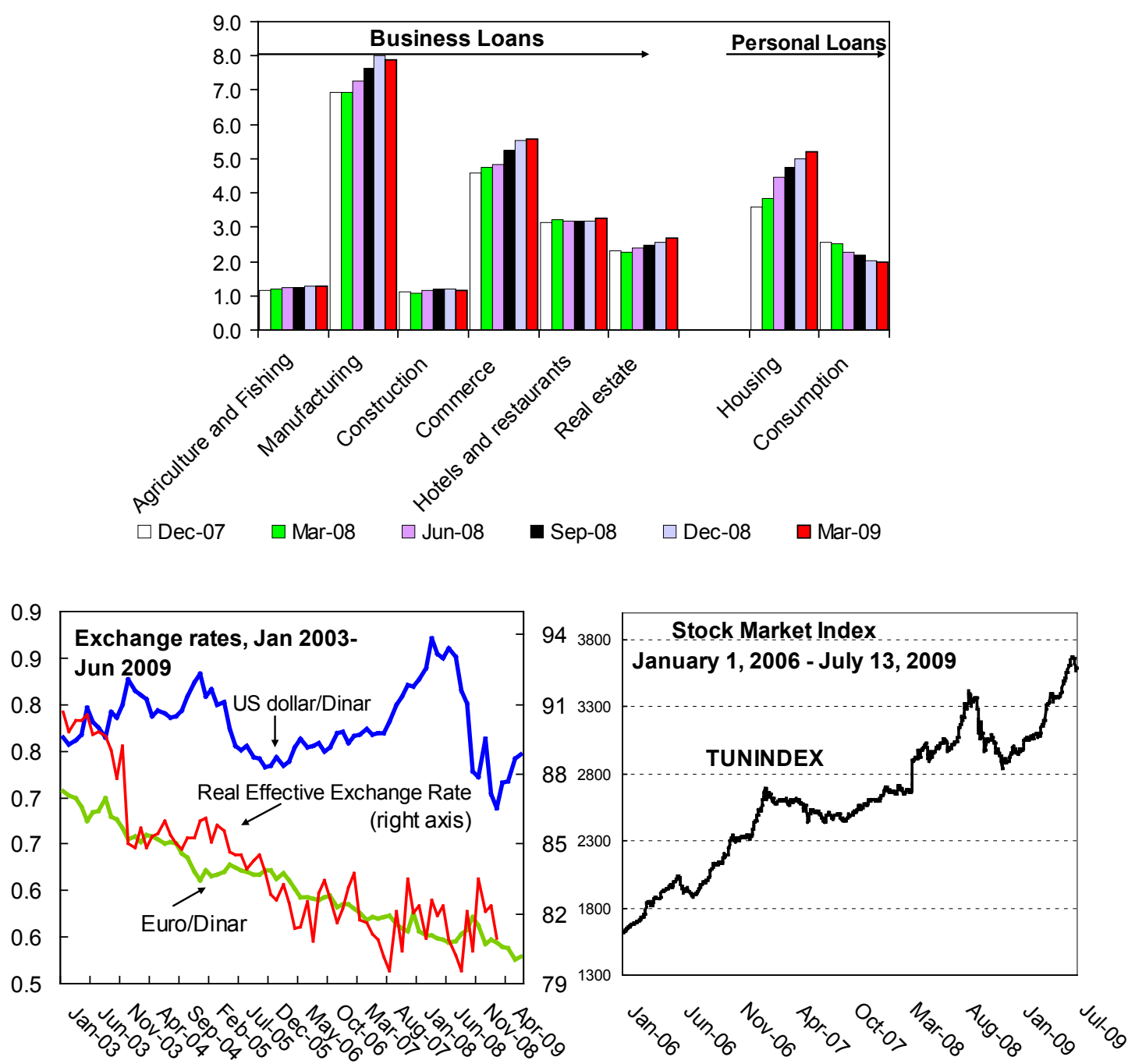
effective exchange rate depreciated by 3.4 percent, reflecting in part the dinar's depreciation against the Euro by 4 percent, while the real effective exchange rate depreciated by 0.3 percent.

- The Tunisian financial sector was not directly affected by the global financial crisis. Banks rely only slightly on external financing and continued attracting strongly growing deposits. Credit to the economy further increased in the first quarter of 2009 , particularly for services, while loans to the manufacturing sector slowed down.

Banks' profitability increased in 2008, which contributed to a buoyant stock market. ${ }^{2}$ This performance was also helped by stable foreign capital and the creation of two investment funds.

\section{OUTLOOK AND RISKS}

\section{Tunisia was relatively insulated from international financial contagion (Box 1) but} is exposed to a slowdown in economic activity in its partner countries. Tunisia has a capital account which is only partially open, low rollover risks, limited need for external borrowing thanks to sizeable privatization receipts, and has been gradually strengthening its banking sector. However, it is vulnerable to adverse shocks to its external demand and their eventual repercussions on its domestic services sector, including the banking system. In particular, spillover effects from European partners are relatively strong and will weigh on Tunisia's growth prospects in the short term. ${ }^{3}$

Tunisia and Main EU Partner Countries Growth in Real GDP (year-on-year in percent) 2002 QI to 2010 QIV

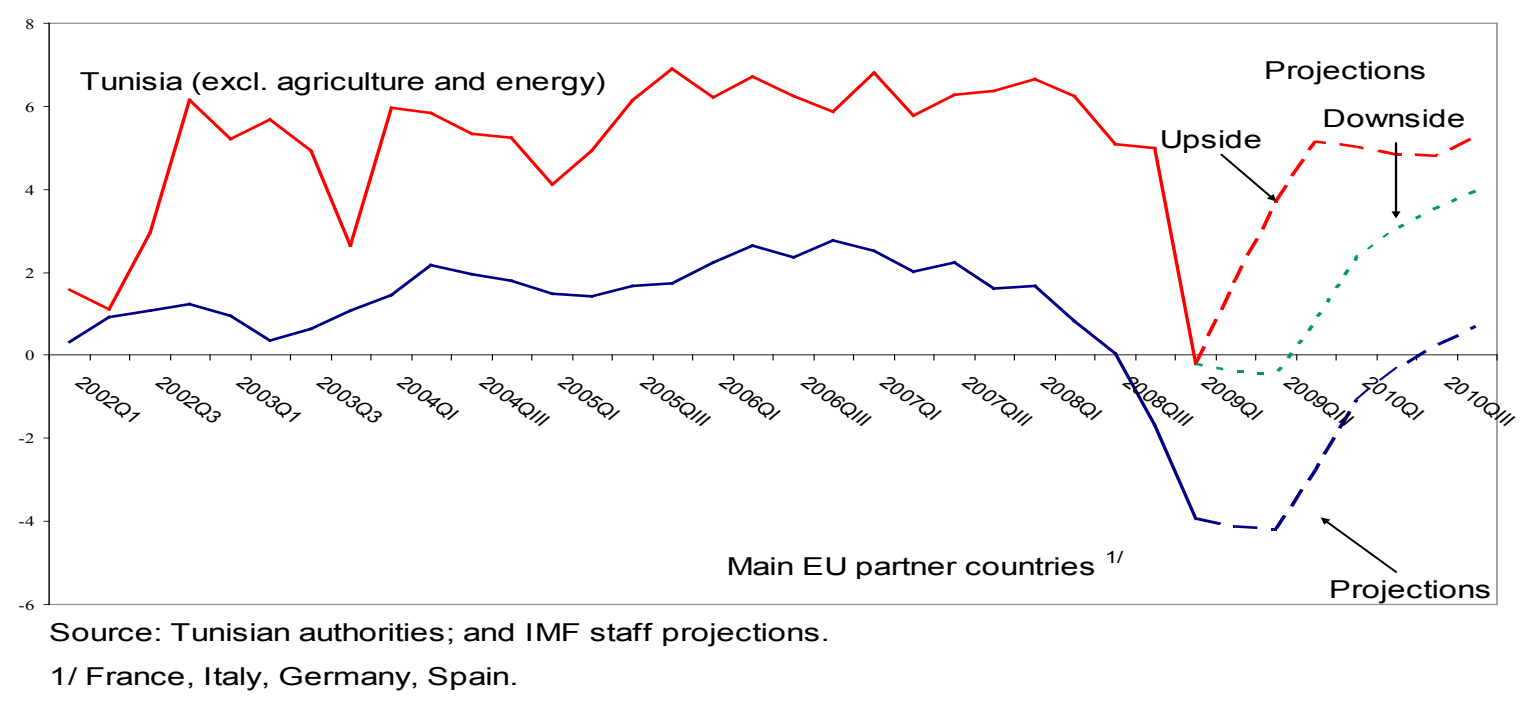

\footnotetext{
${ }^{2}$ Banks account for 49 percent of its capitalization.

${ }^{3}$ See accompanying Selected Issues paper.
} 


\section{Box 1. Limited Exposure to Financial Contagion}

- The capital account is only partially open, which has prevented the integration of Tunisian banks with the international financial system. External assets of Tunisian banks represent only 4 percent of their total assets while external liabilities amount to $81 \frac{1}{2}$ percent of total liabilities. Several restrictions limit capital transactions in foreign currency, including an obligation for banks to transfer their outstanding daily foreign exchange balances to the BCT and ceilings on foreign investment by Tunisian firms, foreign borrowing by banks and foreign investment in Tunisian firms. Foreign ownership — mostly long-term investors in prominent Tunisian holdings - accounts for 25 percent of stock market capitalization.

- Tunisia has no pressing need to borrow on international capital markets. It still disposes of significant resources ( 3 percent of GDP) from the partial privatization of Tunisie Télécom in 2006, and just concluded new lending agreements with the African Development Bank and the World Bank amounting to US\$500 millions over 2009-10.

- Low rollover and interest risks for external debt. Most external debt is contracted over the medium and long term, owed to multilateral and bilateral official lenders with fixed interest rates, and only a small share of external debt is maturing in the next five years.

Structure of Tunisia's External Debt, 2008

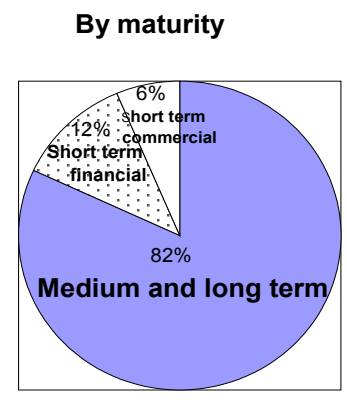

Medium and long term, by currency

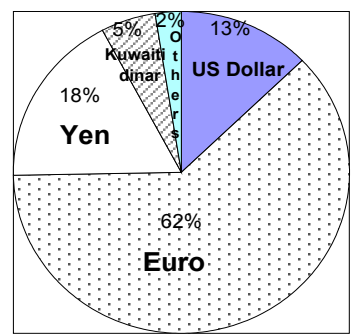

Medium and long term, by average maturity

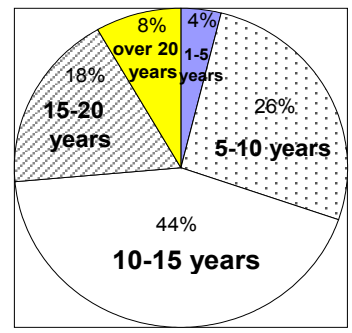

Medium and long term, by type of interest

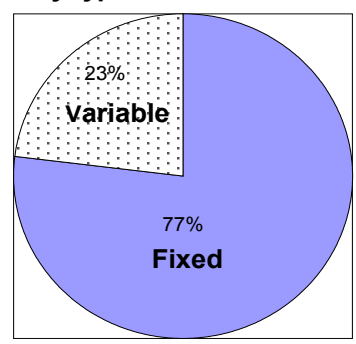

Medium and long term, by creditor

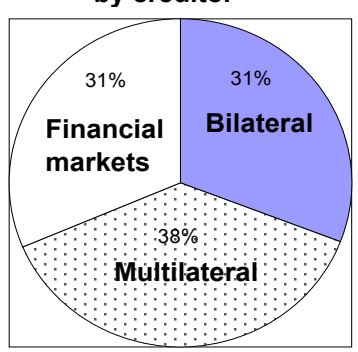

Source: Tunisian authorities; and IMF staff estimates.

- Adequate level of reserves: at end-May 2009, total reserves represented 157 percent of shortterm debt at remaining maturity until end-2009. 
6. The authorities' real GDP growth objective of $\mathbf{3}$ percent in $\mathbf{2 0 0 9}$ may be reached if downside risks do not materialize and Tunisia's fiscal stimulus swiftly impacts demand. In line with the projected recession of about 4 percent in partner countries, exports of goods will decline. Based on developments during the first half of the year, tourism receipts and remittances are projected to be only mildly affected by the crisis this year. ${ }^{4}$ The measures deployed by the authorities to contain the impact of the global crisis, including with the recently adopted fiscal stimulus package and a more accommodating monetary policy, would sustain demand. Moreover, Tunisia's growth will likely benefit from a good cereal crop and a sharp increase in gas production. Nevertheless, such a growth performance-about 7 percentage points higher than in partner countries - is unlikely to prevent a rise in unemployment, and adverse developments in the next few months remain possible.

7. The highly uncertain international environment and the possibly delayed impact of the fiscal stimulus package represent significant downside risks to these projections. The recession and higher unemployment in European partners may depress remittances and tourism receipts during the remainder of the year. A slower rebound of these economies in 2010 would also limit Tunisia's growth performance next year. Moreover, the implementation of the fiscal stimulus measures - particularly accelerating infrastructure investments - may be hampered by bottlenecks.

8. The medium-term outlook is favorable, based on the projected global economic recovery. Tunisia could take further steps to fully benefit from the global economic recovery by pursuing structural reforms, including in the banking sector where continued reinforcement would be beneficial. Once the crisis subsides, fiscal consolidation should bring back the public debt-to-GDP ratio to a declining path.

\section{Policy Discussions}

9. Discussions focused on short-term macroeconomic policies to minimize the impact of the crisis on growth and unemployment while preserving macroeconomic stability and reforms that could further foster productivity gains over the medium term.

\section{A. Fiscal Policy}

\section{Background and staff analysis}

10. Tunisia has leeway for implementing fiscal stimulus measures to mitigate the impact of the recession in partner countries. A fiscal deficit of up to 4 percent of GDP would still leave the public debt-to-GDP ratio below 50 percent (its 2007 level). Revenues are projected to decline significantly in 2009 (by $2 \frac{1}{2}$ percent of GDP) - a reversal from

\footnotetext{
${ }^{4}$ In particular, a drop in tourism from Europe has been offset by increases from neighboring countries.
} 
2008 - but savings on subsidies for petroleum products and staple foods would allow discretionary increases in expenditures of close to $1 \frac{1}{2}$ percent of GDP. Given the abundant liquidity in the banking system, the higher deficit could be financed domestically without crowding out credit to the economy, and avoiding the need for external financing. To be most effective, the fiscal stimulus package should:

- $\quad$ Be executed rapidly so that it can impact growth this year.

- $\quad$ Ensure that expenditure is well-targeted in order to maximize its impact.

- $\quad$ Be extended into 2010, given the still weak global outlook anticipated for 2010. However, maintaining budgetary expenditures in 2010 at their 2009 level may be constrained by a revenue base weakened by the economic slowdown and the capacity to borrow externally.

\section{The fiscal expansion in the short term should be set in a medium-term}

framework where public debt would revert to a declining path once growth firms up. Although Tunisia's public debt-to-GDP ratio has declined in recent years, it remains near the median of countries with similar sovereign ratings. Its experience in 2009 underscores the importance of maintaining fiscal space to counter the impact of shocks on aggregate demand. Two key pillars of that strategy would be to further streamline food and fuel subsidies and implement a reform of the pension scheme to prevent a deficit in the near future. Public Debt: Tunisia vs. Median for Emerging Market Economies with Similar Sovereign Rating ${ }^{1 / 2 /}$
(In percent of GDP)

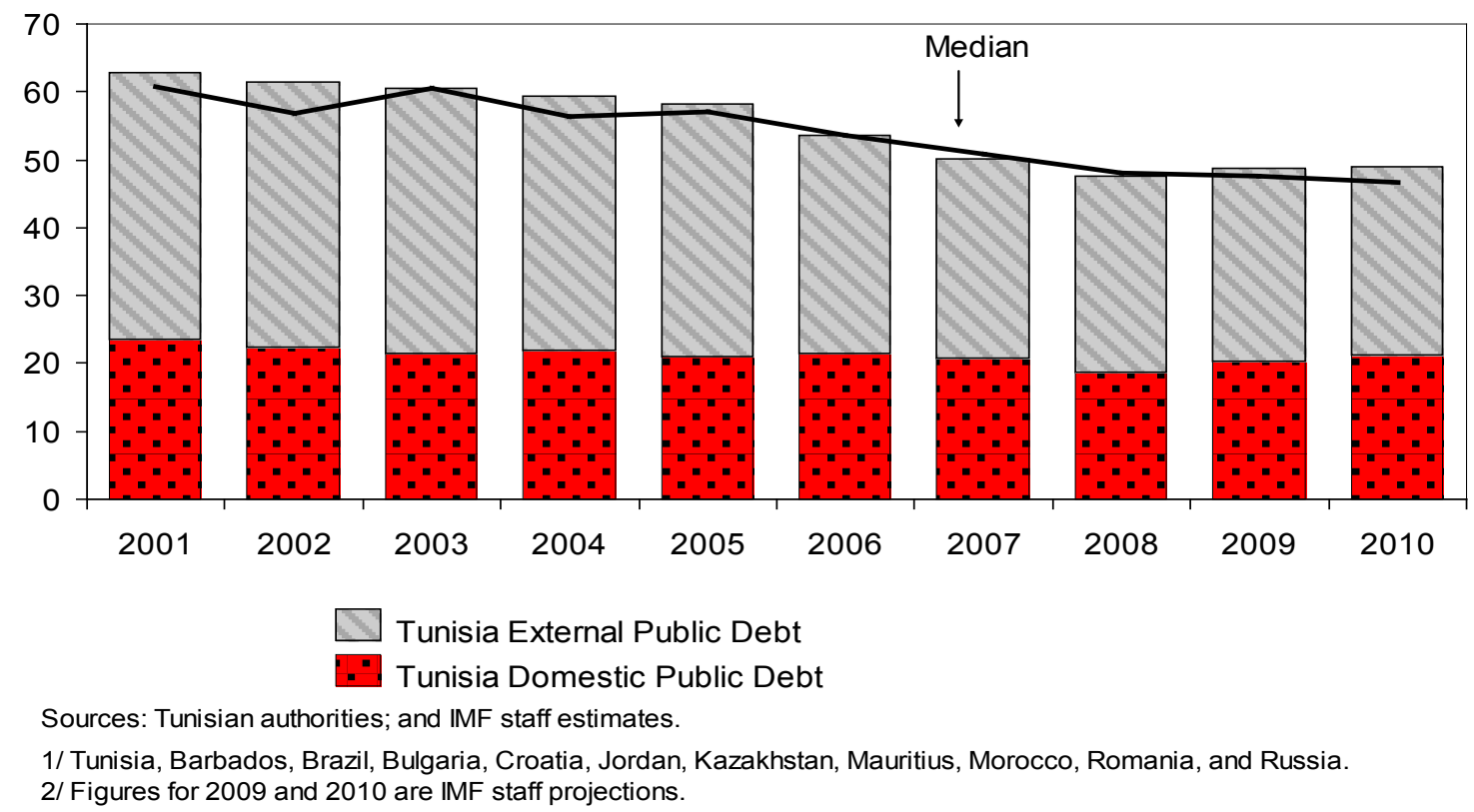


12. Tunisia has a relatively wide social safety net, built over the years, that should help cushion the potential social impact of the crisis. There is no unemployment insurance scheme, but fired workers are eligible for social assistance for up to one year. The coverage of social security is nearly universal and Tunisia has a widespread program of subsidized housing for the poorer segments of the population.

\section{Authorities' views and policy intentions}

\section{Fiscal prudence remains an overarching priority of the authorities, but they} saw the need for reasonable short-term fiscal expansion given the exceptionally depressed external environment. The authorities emphasized their prompt reaction to the crisis through targeted support for exporting firms from end-2008, which limited the number of layoffs. Since the impact of the global crisis could become more widespread and prolonged, the authorities adopted in mid-2009 a fiscal stimulus package of 1.4 percent of GDP in the supplementary budget and extended and expanded the support measures already in place (Box 2). The authorities estimate the effect of the fiscal stimulus on growth at $1 / 2$ percentage point of GDP in $2009,{ }^{5}$ as they are accelerating its implementation and maximizing its impact through labor-intensive investment projects with low import content.

14. The authorities will reevaluate the fiscal stimulus measures for 2010 based on economic and financial developments, but consider the deficit projected in 2009 of 3.8 percent of GDP as an upper bound. Although much improved, they see Tunisia's capacity to weather two consecutive years of a difficult international environment as under test. Therefore, they aim to enhance the revenue base through programs to stimulate energy production, and to improve expenditure targeting.

15. The authorities are resolutely committed to reverting to medium-term fiscal consolidation as soon as growth firms up. They intend to streamline the subsidies for petroleum products based on the price adjustment mechanism introduced in 2009, while maintaining subsidies on staple foods. They consider the administrative costs of effectively targeting the needier households with direct cash transfers as exceeding the cost of the current system, for which direct controls prevent abuse. They also intend to reduce interest on public debt by using privatization receipts for accelerated debt repayment when deemed financially advantageous. Finally, they launched preparation for a pension reform that should address the impact of demographic pressures.

\footnotetext{
${ }^{5}$ Some leakage of the fiscal stimulus package may be expected, in particular for measures in support of the offshore export sector which imports almost all inputs, and employment measures which may stimulate savings and imports.
} 


\section{Box 2. The 2009 Supplementary Budget and Fiscal Stimulus Package}

The authorities adopted in December 2008 several temporary measures to support exporting firms affected by the crisis, including partial exemption of social security contributions, fiscal incentives, and credit guarantees.

An allocation of TD 730 million (1.4 percent of GDP) is provided in the supplementary budget adopted in July 2009 for additional expenditures in 2009 relative to 2008, including for accelerated public investment projects and expanded direct support measures.

The economic recovery program includes the following additional expenditures:

1. Accelerated investment projects: 0.3 percent of GDP;

2. Maintenance (in education, health, and finance): 0.1 percent of GDP;

3. Support for employment (professional training courses, exemption of social security contributions, and a special recruitment program): 0.2 percent of GDP;

4. Support for exports (export guarantees and other budgetary transfers to export credit and insurance companies): 0.1 percent of GDP;

5. Support for enterprise restructuring: 0.3 percent of GDP;

6. Support for energy production (oil exploration and production of electricity): 0.2 percent of GDP;

7. Regional development: 0.2 percent of GDP.

16. The authorities continue to pursue social reforms. The health insurance reform was completed in 2008 to ensure the system's sustainability. The authorities also favor for now active employment policies over an unemployment insurance scheme, as the latter could reduce Tunisia's competitiveness and attractiveness as an investment location. ${ }^{6}$

\section{B. Monetary and Exchange Rate Policy}

\section{Background and staff analysis}

\section{In the context of declining inflation and lower economic activity, a more} accommodating monetary policy helped to sustain demand. Further easing, if warranted, would need to take place only gradually and in coordination with fiscal policy, and take into consideration potential inflationary pressures from the rebound in commodity prices or the

\footnotetext{
${ }^{6}$ An early retirement program for civil servants will be implemented to make room for hiring 5,000-7,000 among university graduates. This would also contribute to improving the delivery of government services.
} 
abundant liquidity. A further deepening of the money market would help enhance monetary policy transmission.

18. The BCT continues to implement the building blocks of an inflation targeting framework for monetary policy. It created a center devoted to the analytical underpinning of the monetary policy framework, and has received EU technical assistance for training and software support.

19. Tunisia's exchange rate remains broadly aligned with its fundamentals, and current account developments and exchange rate policies are consistent with external stability (Box 3). Interventions by the BCT on both sides of the foreign exchange market have declined since 2007, except in October-November 2008 when market participants preferred transacting through the $\mathrm{BCT}$. Tunisia is expected to continue to attract foreign capital to finance a level of investment above its domestic savings, with a sustainable current account deficit of around 3 percent over the medium term.

\section{Authorities' views and policy intentions}

20. The authorities stand ready to cautiously ease monetary policy further to sustain demand as needed. In order to deepen the money market and improve its liquidity management tools, the BCT introduced in February 2009 two new facilities for deposits and borrowing by banks, which resulted in more variable money market rates within the band provided by these facilities. It sees the need for further progress, including by developing the secondary market for Treasury bills, enhancing the role of insurance companies and issuing debt certificates available for foreign investors.

\section{The authorities will pursue preparatory steps towards an inflation-targeting} framework. In that respect, they would welcome technical support from IMF staff for the new center for financial and economic analysis to develop data bases and enhance practical expertise.

22. The authorities reaffirmed their objective of a freely floating exchange rate over the medium term. They noted that the BCT's interventions on foreign exchange markets were for liquidity management purposes, and declined with the easing of restrictions on the capital and current accounts. This trend will continue as Tunisia further liberalizes its capital account. They also remarked the relative stability of Tunisia's exchange rate in contrast with other emerging economies more affected by the financial crisis. 


\section{Box 3. An Assessment of the Exchange Rate Level}

\section{Results using the CGER methodology suggest that the current level of the real effective exchange rate (REER) is broadly in line with fundamentals. ${ }^{1}$}

- $\quad$ Using the CGER's macroeconomic

balance $(\mathrm{MB})$ yields a very small

undervaluation of the REER (1.2 percent).

- $\quad$ The external sustainability (ES) approach suggests an undervaluation of 4.7 percent.

- $\quad$ Tunisia is not included in the CGER sample for the CGER equilibrium real effective exchange rate (EREER) approach.

To complement the study, a country-specific cointegration relationship was estimated for Tunisia. Under this specification, the equilibrium real effective exchange rate is determined by the labor productivity relative to trading partners (prod), the terms of trade (tt), and the trade openness (open):

reer* $=7.36+1.67$ prod $+0.26 \mathrm{tt}-0.91$ open

This approach suggests a small undervaluation of 3.9 percent for 2008 , in line with the estimates under the CGER approach.

This analysis suggests that the depreciation in the REER over the past five years is consistent with an equilibrium real exchange rate depreciation driven by higher openness and a deterioration in the terms of trade that outweigh the Balassa-Samuelson effect from increased productivity gains against trading partners. Alternative measures of the REER (unit labor costs- and producer price index-based) point at a slight improvement in competitiveness in recent years.
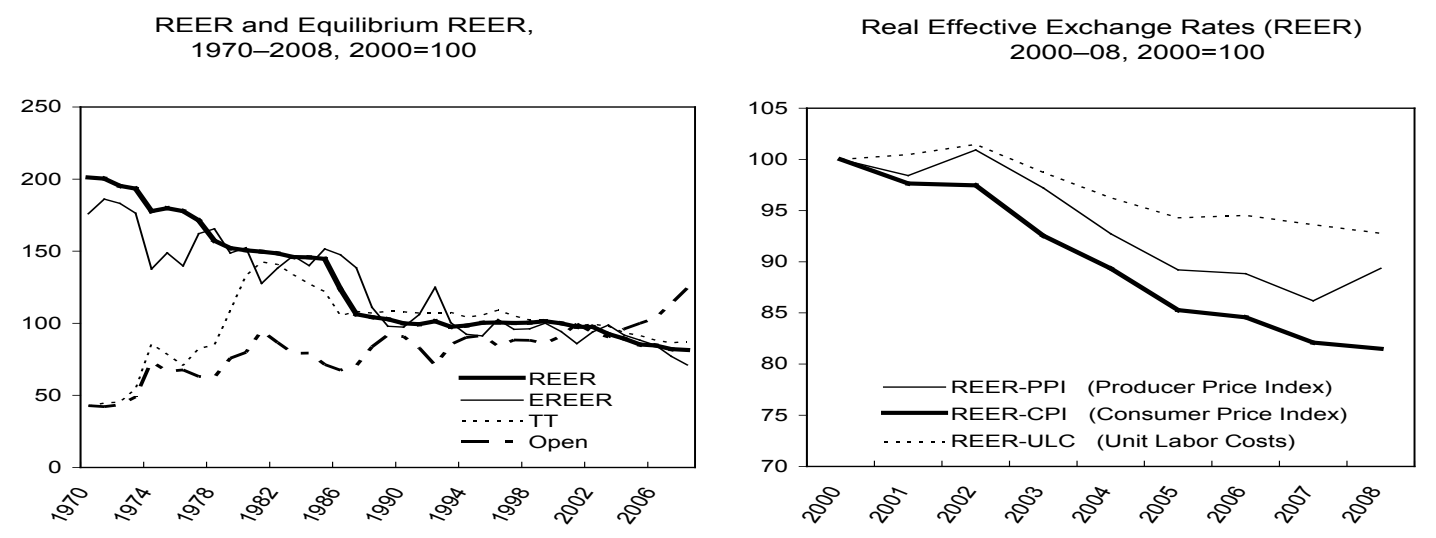

1/ The CGER methodology can be found at this link: (www.imf.org/external/pp/longres.aspx?id=3957) 


\section{Financial Sector Issues}

\section{Background and staff analysis}

\section{Banks soundness indicators continued to improve in 2008 , but the level of} nonperforming loans (NPLs) remains relatively high requiring additional provisioning which hampers banks profitability and development. Continuing recent trend, banking activity, liquidity and profitability increased in 2008, the ratio of NPLs to total loans declined, and the provisioning improved. New NPLs related to the recent credit growth appear very small, while the stock of older NPLs did not decline significantly. The situations of individual banks differ widely: while many of them will be able to achieve the authorities' provisioning objective of 70 percent by end-2009, some banks will need new recapitalization.

\section{Past and international experience show that the banking system can be} vulnerable to the current economic slowdown. Tunisia's tourism crisis in 2002 resulted in a subsequent significant increase in NPLs, yet unresolved. In the context of the current global crisis and its impact on Tunisia, implementing comprehensive stress tests is a priority, since it would further shed light on potential vulnerabilities and a possible need for strengthening measures to reduce them. Fund staff stands ready to assist in this area.

\begin{tabular}{|c|c|c|c|c|c|c|}
\hline \multicolumn{7}{|c|}{ (In percent) } \\
\hline & 2003 & 2004 & 2005 & 2006 & 2007 & $2008^{2 /}$ \\
\hline Capital adequacy ratio ${ }^{3 /}$ & 9.3 & 11.6 & 12.4 & 11.8 & 11.6 & 11.7 \\
\hline Private banks & 8.4 & 12.4 & 13.5 & 12.1 & 9.7 & 11.0 \\
\hline Public banks & 10.8 & 10.1 & 10.0 & 9.3 & 9.9 & 9.6 \\
\hline Former development banks & 54.3 & 55.3 & 50.3 & 46.0 & 38.5 & 36.2 \\
\hline NPLs (percent of total loans) & 24.2 & 23.6 & 20.9 & 19.3 & 17.6 & 15.5 \\
\hline Private banks & 21.6 & 20.4 & 20.0 & 19.0 & 18.1 & 15.3 \\
\hline Public banks & 26.7 & 27.4 & 22.1 & 19.7 & 17.3 & 15.9 \\
\hline Former development banks & 29.6 & 21.5 & 21.0 & 19.6 & 16.0 & 15.0 \\
\hline Provisions (percent of NPLs) & 44.1 & 45.1 & 46.8 & 49.0 & 53.2 & 56.8 \\
\hline Private banks & 39.9 & 43.5 & 45.9 & 48.4 & 52.0 & 55.0 \\
\hline Public banks & 46.2 & 47.6 & 49.1 & 50.2 & 55.0 & 58.1 \\
\hline Former development banks & 62.3 & 23.0 & 28.5 & 42.9 & 48.1 & 63.1 \\
\hline Return on assets & 0.5 & 0.5 & 0.6 & 0.7 & 0.9 & 1.0 \\
\hline Return on equity & 4.6 & 4.8 & 5.9 & 7.0 & 10.1 & 11.2 \\
\hline
\end{tabular}

Source : Tunisian authorities.

1/ International comparisons of the NPL ratio should be interpreted with caution since calculation methods may vary from one country to another. In the case of Tunisia, international standards for classification of NPLs are strictly observed.

2/ Preliminary.

3/ Prior to 2006, the average capital adequacy ratio only includes private and public banks. 
25. A more forward-looking approach to banking supervision could be beneficial, including in the perspective of Basel II. The authorities' careful attention to NPLs and provisioning relates to already materialized credit risks. The capital adequacy ratio, which improved slightly in 2008 but remains below its 2005 level, is a measure of banks' capacity to face future risks. With the implementation of Basel II, requirements for the coverage of credit, market and operational risks will be more stringent, and may necessitate further increases in capital adequacy ratios.

\section{Authorities' views and policy intentions}

26. The authorities emphasized the important steps achieved in strengthening the banking sector and aim at further steady progress in this area. Setting clear objectives for NPLs and provisioning ratios by end-2009 (of 15 and 70 percent, respectively) -in the context of their long-term strategy - induced a proactive stance by all parties that resulted in limiting new NPLs. Banks' capacity for risk assessment improved with effective use of credit risk databases, prudential requirements for governance and control of credit distribution were strengthened, and action plans for troubled banks were agreed and their implementation is closely monitored. The authorities encouraged the capping of dividend distribution and increases in capital, and the government has always been ready to inject new capital in public banks, as demonstrated again in early 2009. They will set new medium-term objectives to drive additional improvements, including more resolute actions to reduce the existing stock of NPLs. The authorities will also support improvement in banks services, including through pooling of logistic and technical resources.

\section{The authorities consider that Tunisia's banking system is not subject to}

significant vulnerabilities. They conducted stress tests based on crisis events experienced in the past by key sectors of the economy to assess additional provisioning needs under such events. Under a scenario combining these shocks, the NPL ratio would not exceed its 2003 peak and the authorities are confident that the shareholders of the most affected banks (public and private) would easily cover the recapitalization needs. They also noted that domestic banks had very limited exposure to the sectors most affected by the global crisis so far (offshore exporting firms).

28. The authorities agree that a more prospective approach to risk management is required. They indicated that preparatory work for Basel II was completed, but its implementation is not yet fully planned. They noted that transparency of the sector improved with the publication of key indicators by banks. 


\section{Other Issues}

\section{Background and staff analysis}

29. Tunisia continues its policy of opening up its economy. Bilateral negotiations with the EU are under way to extend the Association Agreement to services. Tunisia is also actively engaged in the Maghreb integration process, and signed a preferential trade agreement with Algeria in December 2008.

30. Tunisia is implementing policies to improve the business climate and setting up the "Tunis Financial Harbor." Tunisia's procedures for starting a new business were markedly improved last year following the implementation of the 2007 law on economic initiative. Updating customs procedures, which resulted in fewer delays, are expected to continue with the new Customs Code implemented since January 2009. In the context of the Tunis Financial Harbor project, the authorities prepared a bill to harmonize the provision of on- and off-shore financial services consistent with international standards.

\section{Authorities' views and policy intentions}

31. The authorities emphasized their steadfast actions aimed at gradually opening the Tunisian economy despite the currently adverse global environment. They plan to overhaul the environment for services in order to improve their competitiveness ahead of their exposure to international markets.

32. The authorities consider that significantly raising private investment is key to producing lasting gains in productivity. They intend to further improve the business climate and competitiveness in the context of the two new programs financed by the World Bank and the African Development Bank. They look forward to the entry in operations of the Enfidha airport and deep water port which will improve the logistical support to international trade.

\section{Staff Appraisal}

33. Tunisia has weathered the impact of the global crisis relatively well so far, but it still faces downside risks and challenges lie ahead. Highly dependent on Europe for its external demand and FDI, Tunisia saw its exports falling in end-2008, but tourism and remittances have been resilient. Thanks to sound policies implemented over the years, it is facing the crisis with strong fundamentals and has room for short-term expansionary fiscal and monetary policies to sustain demand. The financial system was not affected by the global crisis, but the level of NPLs remains relatively high. Growth may reach 3 percent in 2009 and pick up gradually as the global crisis subsides, but is subject to significant downside risks pertaining to the transmission of the recession in Europe and the speed of impact of fiscal stimulus. This would leave unemployment at a still relatively high level, especially among the youth. 
34. Staff endorses the authorities' temporary expansionary fiscal stance to mitigate the impact of the global crisis. To be most effective, the fiscal stimulus should be executed rapidly, with well-targeted additional expenditures. Staff encourages the authorities to consider extending the fiscal stimulus into 2010, given the still weak outlook anticipated in partner countries.

35. Staff welcomes the authorities' steadfast resolve to revert to fiscal consolidation once growth firms up and bring the public debt-to-GDP ratio - currently near the median of comparable emerging economies - back to a declining trend. A key pillar should be the reduction in subsidies, through the continued effective implementation of the new oil price adjustment mechanism and finding a better targeted mechanism to support the poorer segments of the population. A pension reform should also be implemented in time to avoid a future burden on the budget.

36. The BCT's monetary policy stance has been appropriate, with a cautious easing in 2009 to accommodate demand support. It should be closely coordinated with fiscal policy to allow a timely response. Further easing, if needed, should however be envisaged only gradually, and take into consideration potential renewed inflationary pressures and risks of deteriorating prudential indicators of the banking system.

\section{Staff encourages the authorities to continue implementing the building blocks} for the planned inflation-targeting framework. Efforts to develop analytical and technical underpinnings of this monetary policy framework should be intensified. Further improvements in monetary policy transmission should be pursued as well, including by developing the secondary market for Treasury bills, enhancing the role of insurance companies and issuing debt certificates available for foreign investors.

38. The exchange rate remains broadly aligned with its fundamentals and the authorities' policies are consistent with external stability. The exchange rate policy should remain anchored by the authorities' medium-term objective of a freely floating exchange rate.

39. Prudential indicators continued to improve, but the level of NPLs remains relatively high. While good results were achieved in avoiding the emergence of new NPLs, more resolute efforts to reduce the older stock should be pursued to further strengthen the banking system's resilience, particularly given the gradual opening of the capital account. Individual situations of banks differ widely and will continue to require close monitoring. The staff supports the authorities' plans for further enhancing the quality of bank services.

40. The regulatory and supervisory frameworks should continue to adapt to financial sector developments. A more forward looking approach to banking supervision will be beneficial, including in the context of future implementation of Basel II. Systematic and comprehensive stress testing is needed to better assess the potential vulnerabilities of the banking system and prepare appropriate contingency plans. 
41. The staff welcomes Tunisia's pragmatic and steadfast approach to trade and financial integration, despite the currently adverse global environment. Negotiations with the EU to extend the Association Agreement to services could become a key anchor for a gradual overhaul and liberalization of the services sectors. Tunisia's active participation in the regional integration effort is welcome. Trade diversion should be prevented and geographic diversification enhanced through reduction of most-favored nation tariffs. The staff also welcomes continued improvement in the business climate through ongoing tax and customs administration reforms and programs supported by IFIs.

42. It is proposed that the next Article IV consultation be held on the standard 12-month cycle. 
Table 1. Tunisia: Selected Economic and Financial Indicators, 2006-14

\begin{tabular}{|c|c|c|c|c|c|c|c|c|c|}
\hline & & & Prel. & & & Projec & ctions & & \\
\hline & 2006 & 2007 & 2008 & 2009 & 2010 & 2011 & 2012 & 2013 & 2014 \\
\hline Production and income (percent change) & & & & & & & & & \\
\hline Nominal GDP & 9.6 & 10.2 & 10.3 & 6.8 & 6.4 & 7.9 & 8.4 & 8.5 & 9.0 \\
\hline Real GDP & 5.3 & 6.3 & 4.6 & 3.0 & 4.0 & 5.0 & 5.6 & 5.8 & 6.0 \\
\hline GDP deflator & 4.1 & 3.6 & 5.4 & 3.7 & 2.3 & 2.8 & 2.6 & 2.6 & 2.8 \\
\hline Consumer price index (CPI), average & 4.5 & 3.1 & 5.0 & 3.5 & 3.4 & 3.3 & 3.2 & 3.1 & 3.0 \\
\hline Gross national savings (in percent of GDP) & 22.6 & 23.2 & 23.3 & 22.5 & 24.0 & 23.9 & 24.0 & 24.2 & 24.5 \\
\hline Gross investment (in percent of GDP) & 24.6 & 25.7 & 27.5 & 25.7 & 26.6 & 26.9 & 27.1 & 27.3 & 27.6 \\
\hline External sector (percent change) & & & & & & & & & \\
\hline Exports of goods, f.o.b. (in \$) & 9.9 & 29.6 & 26.6 & -21.5 & 5.8 & 6.9 & 6.3 & 6.4 & 9.0 \\
\hline Imports of goods, f.o.b. (in \$) & 12.8 & 26.9 & 28.7 & -21.4 & 8.2 & 7.5 & 7.0 & 6.7 & 8.7 \\
\hline Exports of goods, f.o.b. (volume) & 6.3 & 15.5 & 4.1 & -3.8 & 3.5 & 4.0 & 4.2 & 4.4 & 4.9 \\
\hline Import of goods, f.o.b. (volume) & 5.1 & 10.9 & 6.8 & 0.1 & 3.7 & 3.4 & 3.4 & 3.4 & 3.4 \\
\hline Trade balance (in percent of GDP) & -8.1 & -8.1 & -9.8 & -8.2 & -9.3 & -9.7 & -10.0 & -10.1 & -10.2 \\
\hline Current account, excluding grants (in percent of GDP) & -2.0 & -2.5 & -4.2 & -3.3 & -2.6 & -3.0 & -3.1 & -3.1 & -3.1 \\
\hline Foreign direct investment (percent of GDP) & 10.4 & 6.2 & 5.8 & 3.1 & 3.2 & 3.4 & 3.5 & 3.8 & 4.0 \\
\hline Terms of trade (deterioration -) & -3.6 & -1.9 & 1.0 & 3.9 & -2.1 & -1.2 & -1.3 & -1.3 & -1.2 \\
\hline Real effective exchange rate (depreciation -) $1 /$ & -0.8 & -2.8 & -0.9 & $\ldots$ & $\cdots$ & $\cdots$ & $\cdots$ & $\cdots$ & $\cdots$ \\
\hline $\begin{array}{l}\text { Central government (percent of GDP, unless } \\
\text { otherwise indicated) } 2 /\end{array}$ & & & & & & & & & \\
\hline Total revenue, excluding grants and privatization & 23.4 & 23.8 & 26.2 & 23.7 & 23.3 & 23.2 & 23.0 & 22.8 & 22.7 \\
\hline Total expenditure and net lending & 26.5 & 26.7 & 27.3 & 27.5 & 27.0 & 26.2 & 25.9 & 25.7 & 25.5 \\
\hline Central government balance, excluding grants and & & & & & & & & & \\
\hline privatization & -3.0 & -2.9 & -1.2 & -3.8 & -3.8 & -3.0 & -3.0 & -2.9 & -2.8 \\
\hline Central government balance, including grants, & & & & & & & & & \\
\hline excluding privatization & -2.9 & -2.8 & -0.8 & -3.6 & -3.6 & -2.9 & -2.9 & -2.8 & -2.8 \\
\hline Total government debt (foreign and domestic) & 53.7 & 50.0 & 47.5 & 48.7 & 49.0 & 48.0 & 47.4 & 46.7 & 45.8 \\
\hline Foreign currency public debt (percent of total debt) & 59.8 & 58.3 & 60.8 & 58.0 & 56.6 & 54.1 & 51.4 & 48.8 & 46.1 \\
\hline Money and credit (percent change) & & & & & & & & & \\
\hline Credit to the economy & 6.6 & 9.7 & 13.6 & 8.0 & $\ldots$ & $\ldots$ & $\ldots$ & $\ldots$ & $\ldots$ \\
\hline Broad money (M3) 3/ & 11.4 & 12.5 & 14.4 & 10.9 & $\ldots$ & $\ldots$ & $\ldots$ & $\ldots$ & $\ldots$ \\
\hline Velocity of circulation (GDP/M3) & 1.56 & 1.53 & 1.47 & 1.42 & $\ldots$ & $\ldots$ & $\ldots$ & $\ldots$ & $\ldots$ \\
\hline Interest rate (money market rate, in percent, e.o.p) 4/ & 5.33 & 5.10 & 5.19 & 4.30 & $\cdots$ & $\cdots$ & $\cdots$ & $\cdots$ & $\cdots$ \\
\hline Official reserves & & & & & & & & & \\
\hline Gross official reserves (US $\$$ billions, e.o.p) $5 /$ & 6.8 & 7.9 & 9.0 & 9.7 & 11.0 & 12.0 & 13.2 & 14.5 & 16.2 \\
\hline In months of imports of goods and services, c.i.f. & 5.0 & 4.6 & 4.1 & 5.6 & 5.9 & 6.0 & 6.2 & 6.4 & 6.6 \\
\hline Total external debt & & & & & & & & & \\
\hline External debt (US\$ billions) & 18.5 & 20.1 & 20.6 & 20.5 & 21.1 & 21.6 & 22.4 & 23.1 & 24.0 \\
\hline External debt (in percent of GDP) & 58.1 & 53.9 & 53.7 & 52.5 & 52.3 & 50.5 & 48.9 & 47.2 & 45.8 \\
\hline Debt service ratio (percent of exports of GNFS) & 18.6 & 13.3 & 8.8 & 11.2 & 9.5 & 10.7 & 9.5 & 8.6 & 8.3 \\
\hline Financial market indicators & & & & & & & & & \\
\hline Stock market index 6/ & 2,331 & 2,614 & 2,892 & 3,589 & $\cdots$ & $\ldots$ & ... & $\ldots$ & $\ldots$ \\
\hline Memorandum items: & & & & & & & & & \\
\hline GDP at current prices (TD millions) & 41,408 & 45,629 & 50,325 & 53,727 & 57,153 & 61,692 & 66,887 & 72,578 & 79,093 \\
\hline GDP at current prices (US\$ billions) & 31.9 & 37.4 & 38.4 & 39.0 & 40.5 & 42.9 & 45.7 & 48.9 & 52.4 \\
\hline GDP per capita (US\$) & 3,152 & 3,656 & 3,720 & 3,744 & 3,841 & 4,031 & 4,258 & 4,505 & 4,785 \\
\hline Unemployment rate (in percent) & 14.3 & 14.1 & 14.2 & $\ldots$ & $\ldots$ & $\ldots$ & $\ldots$ & $\ldots$ & $\ldots$ \\
\hline Population (millions) & 10.1 & 10.2 & 10.3 & 10.4 & 10.5 & 10.6 & 10.7 & 10.8 & 11.0 \\
\hline Exchange rate: dinar/US\$ (average) & 1.33 & 1.28 & 1.23 & $\ldots$ & $\ldots$ & $\ldots$ & $\ldots$ & $\ldots$ & $\ldots$ \\
\hline
\end{tabular}

Sources: Tunisian authorities; and staff estimates and projections.

$1 /$ Information Notice System.

2/ Excludes the social security accounts.

3/ Financial system (deposit money banks and development banks).

4/ The rate for 2008 is the average rate for December and the rate for 2009 is for April.

$5 /$ End of year reserves over current year imports of goods and services.

6/ TUNINDEX. (1000 = 4/1/1998). 2009 data from July 13. 
Table 2. Tunisia: Balance of Payments, 2006-14

(In millions of U.S. dollars, unless otherwise indicated)

\begin{tabular}{|c|c|c|c|c|c|c|c|c|c|}
\hline & \multirow[b]{2}{*}{2006} & \multirow[b]{2}{*}{2007} & \multirow{2}{*}{$\frac{\text { Prel. }}{2008}$} & \multicolumn{6}{|c|}{ Projections } \\
\hline & & & & 2009 & 2010 & 2011 & 2012 & 2013 & 2014 \\
\hline Current account & -620 & -904 & $-1,718$ & $-1,285$ & $-1,061$ & $-1,300$ & $-1,432$ & $-1,544$ & $-1,646$ \\
\hline Trade balance & $-2,513$ & $-2,876$ & $-4,010$ & $-3,179$ & $-3,814$ & $-4,203$ & $-4,604$ & $-4,975$ & $-5,366$ \\
\hline Exports & 11,689 & 15,148 & 19,183 & 15,060 & 15,929 & 17,029 & 18,110 & 19,263 & 20,992 \\
\hline Energy & 1,516 & 2,449 & 3,311 & 2,271 & 3,037 & 3,307 & 3,534 & 3,744 & 3,970 \\
\hline Nonenergy & 10,173 & 12,699 & 15,872 & 12,789 & 12,892 & 13,722 & 14,576 & 15,520 & 17,022 \\
\hline Imports & $-14,202$ & $-18,024$ & $-23,194$ & $-18,239$ & $-19,743$ & $-21,232$ & $-22,714$ & $-24,238$ & $-26,358$ \\
\hline Energy & $-2,148$ & $-2,343$ & $-3,988$ & $-2,114$ & $-2,683$ & $-2,902$ & $-3,076$ & $-3,230$ & $-3,391$ \\
\hline Nonenergy & $-12,054$ & $-15,681$ & $-19,206$ & $-16,125$ & $-17,060$ & $-18,330$ & $-19,638$ & $-21,008$ & $-22,966$ \\
\hline Of which: Nonfood & $-11,061$ & $-14,087$ & $-17,095$ & $-14,455$ & $-15,319$ & $-16,464$ & $-17,690$ & $-18,976$ & $-20,858$ \\
\hline Services and transfers (net) & 1,894 & 1,972 & 2,292 & 1,895 & 2,753 & 2,902 & 3,172 & 3,431 & 3,720 \\
\hline Nonfactor & 1,924 & 2,203 & 2,710 & 2,255 & 2,289 & 2,424 & 2,594 & 2,786 & 3,124 \\
\hline Of which: Tourism & 2,123 & 2,402 & 2,751 & 2,509 & 2,559 & 2,677 & 2,834 & 3,015 & 3,257 \\
\hline Factor Services and Transfers (net) & -30 & -231 & -418 & -360 & 464 & 479 & 578 & 645 & 596 \\
\hline Of which: Workers' remittances & 1,510 & 1,716 & 1,937 & 1,793 & 1,829 & 1,875 & 1,944 & 2,030 & 2,150 \\
\hline Interest payments on external debt & -698 & -731 & -742 & -657 & -574 & -592 & -579 & -596 & -609 \\
\hline Capital and financial account & 2,705 & 1,610 & 3,327 & 1,516 & 2,453 & 2,261 & 2,625 & 2,881 & 3,266 \\
\hline Excluding grants & 2,556 & 1,465 & 3,230 & 1,394 & 2,332 & 2,191 & 2,556 & 2,814 & 3,199 \\
\hline Capital account & 145 & 140 & 91 & 117 & 116 & 65 & 64 & 63 & 62 \\
\hline Financial account & 2,560 & 1,470 & 3,236 & 1,399 & 2,337 & 2,196 & 2,561 & 2,819 & 3,204 \\
\hline Direct foreign investment (net) & 3,305 & 1,545 & 2,336 & 1,287 & 1,364 & 1,526 & 1,686 & 1,946 & 2,181 \\
\hline Medium- and long-term loans (net) & -789 & -226 & -9 & -4 & 559 & 225 & 406 & 372 & 313 \\
\hline Disbursement & 1,458 & 1,683 & 1,416 & 1,553 & 1,954 & 2,005 & 2,066 & 1,931 & 1,976 \\
\hline Amortization & $-2,247$ & $-1,910$ & $-1,425$ & $-1,557$ & $-1,396$ & $-1,780$ & $-1,660$ & $-1,559$ & $-1,664$ \\
\hline Short-term capital & 44 & 151 & 909 & 116 & 414 & 446 & 469 & 501 & 710 \\
\hline Errors and omissions & 0 & 0 & 0 & 0 & 0 & 0 & 0 & 0 & 0 \\
\hline Overall balance & 2,086 & 706 & 1,609 & 231 & 1,392 & 961 & 1,193 & 1,337 & 1,620 \\
\hline Changes in gross reserves 1 / & $-2,364$ & $-1,148$ & $-1,027$ & -713 & $-1,323$ & -953 & $-1,209$ & $-1,355$ & $-1,633$ \\
\hline \multicolumn{10}{|l|}{ Memorandum items: } \\
\hline Current account balance/GDP (in percent) & -2.0 & -2.5 & -4.2 & -3.3 & -2.6 & -3.0 & -3.1 & -3.1 & -3.1 \\
\hline Reserves (in billions of US $\$$ ) & 6.8 & 7.9 & 9.0 & 9.7 & 11.0 & 12.0 & 13.2 & 14.5 & 16.2 \\
\hline Reserves in months of imports of goods $2 /$ & 5.4 & 5.0 & 4.4 & 6.0 & 6.3 & 6.4 & 6.6 & 6.8 & 6.9 \\
\hline Reserves in months of imports of goods and services $2 /$ & 5.0 & 4.6 & 4.1 & 5.6 & 5.9 & 6.0 & 6.2 & 6.4 & 6.6 \\
\hline Reserves/total short term external debt (percent) $3 /$ & 202.2 & 199.2 & 207.2 & 228.5 & 242.5 & 244.2 & 249.1 & 254.8 & $\ldots$ \\
\hline Excluding nonresidents deposits & 398.7 & 427.0 & 462.1 & 432.8 & 458.9 & 461.2 & 467.3 & 473.4 & $\ldots$ \\
\hline Reserves/short-term debt (on remaining maturity & & & & & & & & & \\
\hline basis) (in percent) & 136.7 & 146.4 & 150.3 & 171.2 & 173.7 & 181.9 & 192.0 & 254.8 & $\ldots$ \\
\hline Excluding nonresidents deposits & 184.6 & 222.3 & 273.3 & 255.0 & 291.1 & 274.3 & 294.9 & 314.6 & ... \\
\hline External medium- and long-term debt (in billions of US\$) & 15.2 & 16.2 & 16.3 & 16.3 & 16.6 & 16.7 & 17.1 & 17.4 & 17.7 \\
\hline External medium- and long-term debt/GDP (in percent) & 47.5 & 43.2 & 42.4 & 41.7 & 41.1 & 39.0 & 37.3 & 35.5 & 33.8 \\
\hline External short-term debt (in billions of US $\$$ ) & 3.4 & 4.0 & 4.3 & 4.2 & 4.5 & 4.9 & 5.3 & 5.7 & 6.3 \\
\hline External short-term debt/GDP (in percent) & 10.5 & 10.7 & 11.3 & 10.8 & 11.2 & 11.4 & 11.5 & 11.7 & 12.0 \\
\hline Debt service ratio (as percent XGS, including IMF) & 18.6 & 13.3 & 8.8 & 11.2 & 9.5 & 10.7 & 9.5 & 8.6 & 8.3 \\
\hline Goods export real growth (in percent) & 6.3 & 15.5 & 4.1 & -3.8 & 3.5 & 4.0 & 4.2 & 4.4 & 4.9 \\
\hline Nonenergy & 8.7 & 11.2 & 5.0 & -6.2 & 2.4 & 4.0 & 4.1 & 4.4 & 5.0 \\
\hline Goods import real growth (in percent) & 5.1 & 10.9 & 6.8 & 0.1 & 3.7 & 3.4 & 3.4 & 3.4 & 3.4 \\
\hline Nonenergy & 5.6 & 12.7 & 5.8 & 2.1 & 3.7 & 3.4 & 3.4 & 3.4 & 3.4 \\
\hline
\end{tabular}

Sources: Tunisian authorities; and Fund staff estimates and projections.

$1 /$ Differs from the overall balance because of valuation effects.

2/ End-of-year reserves over current year imports.

$3 /$ Short term defined as 1 year and less. 
Table 3. Tunisia: Central Government Financial Operations, 2006-14 1/

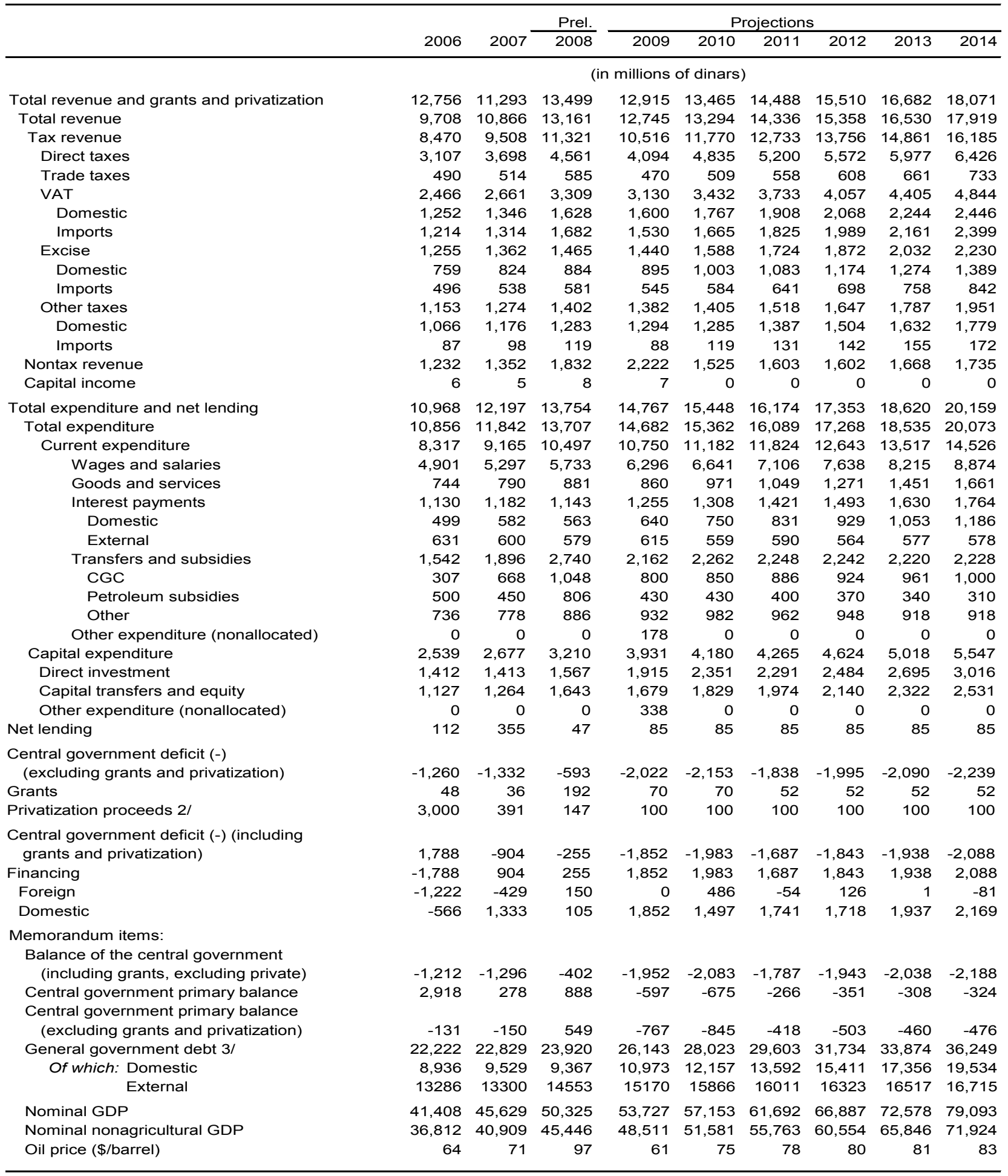


Table 3. Tunisia: Central Government Financial Operations, 2006-14 1/ (concluded)

\begin{tabular}{|c|c|c|c|c|c|c|c|c|c|}
\hline & & & Prel. & & & jection & & & \\
\hline & 2006 & 2007 & 2008 & 2009 & 2010 & 2011 & 2012 & 2013 & 2014 \\
\hline & & & & percen & of GD & & & & \\
\hline Total revenue and grants and privatization & 30.8 & 24.7 & 26.8 & 24.0 & 23.6 & 23.5 & 23.2 & 23.0 & 22.8 \\
\hline Total revenue & 23.4 & 23.8 & 26.2 & 23.7 & 23.3 & 23.2 & 23.0 & 22.8 & 22.7 \\
\hline Tax revenue & 20.5 & 20.8 & 22.5 & 19.6 & 20.6 & 20.6 & 20.6 & 20.5 & 20.5 \\
\hline Direct taxes & 7.5 & 8.1 & 9.1 & 7.6 & 8.5 & 8.4 & 8.3 & 8.2 & 8.1 \\
\hline Trade taxes (in percent of imports) & 2.9 & 2.4 & 2.3 & 2.3 & 2.0 & 2.0 & 2.0 & 2.0 & 2.0 \\
\hline VAT & 6.0 & 5.8 & 6.6 & 5.8 & 6.0 & 6.1 & 6.1 & 6.1 & 6.1 \\
\hline Domestic & 3.0 & 3.0 & 3.2 & 3.1 & 3.1 & 3.1 & 3.1 & 3.1 & 3.1 \\
\hline Imports & 2.9 & 2.9 & 3.3 & 2.8 & 2.9 & 3.0 & 3.0 & 3.0 & 3.0 \\
\hline Imports (in percent of imports) & 7.1 & 6.1 & 6.6 & 6.6 & 6.5 & 6.5 & 6.5 & 6.5 & 6.5 \\
\hline Excise & 3.0 & 3.0 & 2.9 & 2.7 & 2.8 & 2.8 & 2.8 & 2.8 & 2.8 \\
\hline Domestic & 1.8 & 1.8 & 1.8 & 1.8 & 1.8 & 1.8 & 1.8 & 1.8 & 1.8 \\
\hline Imports & 1.2 & 1.2 & 1.2 & 1.0 & 1.0 & 1.0 & 1.0 & 1.0 & 1.1 \\
\hline Other taxes & 2.8 & 2.8 & 2.8 & 2.6 & 2.5 & 2.5 & 2.5 & 2.5 & 2.5 \\
\hline Domestic & 2.6 & 2.6 & 2.5 & 2.2 & 2.2 & 2.2 & 2.2 & 2.2 & 2.2 \\
\hline Imports & 0.2 & 0.2 & 0.2 & 0.2 & 0.2 & 0.2 & 0.2 & 0.2 & 0.2 \\
\hline Imports (in percent of imports) & 0.5 & 0.5 & 0.5 & 0.5 & 0.5 & 0.5 & 0.5 & 0.5 & 0.5 \\
\hline Nontax revenue & 3.0 & 3.0 & 3.6 & 4.1 & 2.7 & 2.6 & 2.4 & 2.3 & 2.2 \\
\hline Capital income & 0.0 & 0.0 & 0.0 & 0.0 & 0.0 & 0.0 & 0.0 & 0.0 & 0.0 \\
\hline Total expenditure and net lending & 26.5 & 26.7 & 27.3 & 27.5 & 27.0 & 26.2 & 25.9 & 25.7 & 25.5 \\
\hline Total expenditure & 26.2 & 26.0 & 27.2 & 27.3 & 26.9 & 26.1 & 25.8 & 25.5 & 25.4 \\
\hline Current expenditure & 20.1 & 20.1 & 20.9 & 20.0 & 19.6 & 19.2 & 18.9 & 18.6 & 18.4 \\
\hline Wages and salaries & 11.8 & 11.6 & 11.4 & 11.7 & 11.6 & 11.5 & 11.4 & 11.3 & 11.2 \\
\hline Goods and services & 1.8 & 1.7 & 1.8 & 1.6 & 1.7 & 1.7 & 1.9 & 2.0 & 2.1 \\
\hline Interest payments & 2.7 & 2.6 & 2.3 & 2.3 & 2.3 & 2.3 & 2.2 & 2.2 & 2.2 \\
\hline Domestic & 1.2 & 1.3 & 1.1 & 1.2 & 1.3 & 1.3 & 1.4 & 1.5 & 1.5 \\
\hline External & 1.5 & 1.3 & 1.2 & 1.1 & 1.0 & 1.0 & 0.8 & 0.8 & 0.7 \\
\hline Transfers and subsidies & 3.7 & 4.2 & 5.4 & 4.0 & 4.0 & 3.6 & 3.4 & 3.1 & 2.8 \\
\hline CGC & 0.7 & 1.5 & 2.1 & 1.5 & 1.5 & 1.4 & 1.4 & 1.3 & 1.3 \\
\hline Other expenditure (nonallocated) & 0.0 & 0.0 & 0.0 & 0.3 & 0.0 & 0.0 & 0.0 & 0.0 & 0.0 \\
\hline Capital expenditure & 6.1 & 5.9 & 6.4 & 7.3 & 7.3 & 6.9 & 6.9 & 6.9 & 7.0 \\
\hline Direct investment & 3.4 & 3.1 & 3.1 & 3.6 & 4.1 & 3.7 & 3.7 & 3.7 & 3.8 \\
\hline Capital transfers and equity & 2.7 & 2.8 & 3.3 & 3.1 & 3.2 & 3.2 & 3.2 & 3.2 & 3.2 \\
\hline Other expenditure (nonallocated) & 0.0 & 0.0 & 0.0 & 0.6 & 0.0 & 0.0 & 0.0 & 0.0 & 0.0 \\
\hline Net lending & 0.3 & 0.8 & 0.1 & 0.2 & 0.1 & 0.1 & 0.1 & 0.1 & 0.1 \\
\hline $\begin{array}{l}\text { Central government deficit (-), (excluding g } \\
\text { and privatization) }\end{array}$ & -3.0 & -2.9 & -1.2 & -3.8 & -3.8 & -3.0 & -3.0 & -2.9 & -2.8 \\
\hline Grants & 0.1 & 0.1 & 0.4 & 0.1 & 0.1 & 0.1 & 0.1 & 0.1 & 0.1 \\
\hline Privatization proceeds $2 /$ & 7.2 & 0.9 & 0.3 & 0.2 & 0.2 & 0.2 & 0.1 & 0.1 & 0.1 \\
\hline Central government deficit (-), (including gr & & & & & & & & & \\
\hline and privatization) & 4.3 & -2.0 & -0.5 & -3.4 & -3.5 & -2.7 & -2.8 & -2.7 & -2.6 \\
\hline Financing & -4.3 & 2.0 & 0.5 & 3.4 & 3.5 & 2.7 & 2.8 & 2.7 & 2.6 \\
\hline Foreign & -3.0 & -0.9 & 0.3 & 0.0 & 0.8 & -0.1 & 0.2 & 0.0 & -0.1 \\
\hline Domestic & -1.4 & 2.9 & 0.2 & 3.4 & 2.6 & 2.8 & 2.6 & 2.7 & 2.7 \\
\hline Memorandum items: & & & & & & & & & \\
\hline Balance of the central government (inclu & -29 & 28 & -08 & -36 & -36 & -29 & -29 & -28 & -28 \\
\hline Central government primary balance & $\begin{array}{r}-2.5 \\
7.0\end{array}$ & $\begin{array}{r}-2.0 \\
0.6\end{array}$ & $\begin{array}{r}-0.0 \\
1.8\end{array}$ & $\begin{array}{l}-3.0 \\
-1.1\end{array}$ & $\begin{array}{l}-3.0 \\
-1.2\end{array}$ & $\begin{array}{l}-2.9 \\
-0.4\end{array}$ & -0.5 & -0.4 & $\begin{array}{l}-2.0 \\
-0.4\end{array}$ \\
\hline Central government primary balance (ex & & & & & & & & & \\
\hline grants and privatization) & -0.3 & -0.3 & 1.1 & -1.4 & -1.5 & -0.7 & -0.8 & -0.6 & -0.6 \\
\hline General government debt 3/ & 53.7 & 50.0 & 47.5 & 48.7 & 49.0 & 48.0 & 47.4 & 46.7 & 45.8 \\
\hline Of which: Domestic & 21.6 & 20.9 & 18.6 & 20.4 & 21.3 & 22.0 & 23.0 & 23.9 & 24.7 \\
\hline External & 32.1 & 29.1 & 28.9 & 28.2 & 27.8 & 26.0 & 24.4 & 22.8 & 21.1 \\
\hline
\end{tabular}

Sources: Tunisian authorities; and staff estimates.

$1 /$ Includes special funds, fonds de concours. Does not include the social security system (CSS).

2/ Privatization receipts from Tunisie Telecom (TT) were about TD 3000 millions in 2006.

3/ Gross debt: includes debt held by social security funds (CSS); excludes debt of public enterprises. 
Table 4. Tunisia: Monetary Survey (Financial System), 2005-09

\begin{tabular}{|c|c|c|c|c|c|}
\hline & 2005 & 2006 & 2007 & $\frac{\text { Prel. }}{2008}$ & $\frac{\text { Proj. }}{2009}$ \\
\hline & \multicolumn{5}{|c|}{ (In millions of dinars) } \\
\hline Foreign assets (net) & 4,112 & 6,876 & 7,807 & 9,459 & 10,988 \\
\hline Foreign assets & 7,341 & 10,230 & 11,715 & 13,662 & 15,641 \\
\hline $\mathrm{BCT}$ & 6,060 & 8,837 & 9,719 & 11,773 & 13,352 \\
\hline Foreign liabilities & $-3,229$ & $-3,354$ & $-3,908$ & $-4,204$ & $-4,653$ \\
\hline Net domestic assets & 19,708 & 19,670 & 22,046 & 24,693 & 26,883 \\
\hline Domestic credit & 28,149 & 30,745 & 33,777 & 37,806 & 41,027 \\
\hline Credit to the government (net) & 3,611 & 4,589 & 5,096 & 5,223 & 5,834 \\
\hline Central bank net credit & -636 & -243 & -256 & -326 & -326 \\
\hline Commercial banks & 2,275 & 2,609 & 2,817 & 2,501 & 3,112 \\
\hline Credit to the economy & 24,538 & 26,157 & 28,681 & 32,584 & 35,194 \\
\hline Other items (net) & $-8,441$ & $-11,075$ & $-11,731$ & $-13,114$ & $-14,145$ \\
\hline Money plus quasi-money (M2) & 22,129 & 24,834 & 28,197 & 32,289 & 35,421 \\
\hline Money (M1) & 8,742 & 9,871 & 11,083 & 12,387 & 13,589 \\
\hline Currency & 3,478 & 3,873 & 4,099 & 4,400 & 4,827 \\
\hline Demand deposits & 5,263 & 5,998 & 6,984 & 7,987 & 8,762 \\
\hline Quasi-money & 13,388 & 14,963 & 17,115 & 19,902 & 21,832 \\
\hline Long-term deposits (M3-M2) & 1,691 & 1,712 & 1,656 & 1,863 & 2,449 \\
\hline \multirow[t]{2}{*}{ Broad money (M3 ) 1/ } & 23,821 & 26,546 & 29,853 & 34,151 & 37,870 \\
\hline & \multicolumn{5}{|c|}{ (Annual rate of change in percent) } \\
\hline Foreign assets (net) & 31.5 & 67.2 & 13.5 & 21.2 & 16.2 \\
\hline Domestic credit & 6.8 & 9.2 & 9.9 & 11.9 & 8.5 \\
\hline Credit to government (net) & 10.0 & 27.1 & 11.1 & 2.5 & 11.7 \\
\hline Credit to the economy & 6.3 & 6.6 & 9.7 & 13.6 & 8.0 \\
\hline Money and quasi-money (M2) & 11.5 & 12.2 & 13.5 & 14.5 & 9.7 \\
\hline \multirow[t]{2}{*}{ Broad money (M3 ) } & 11.0 & 11.4 & 12.5 & 14.4 & 10.9 \\
\hline & \multicolumn{5}{|c|}{ (Changes in percent of initial stock of M3) } \\
\hline Foreign assets (net) & 4.6 & 11.6 & 3.5 & 5.5 & 4.5 \\
\hline Domestic credit & 8.3 & 10.9 & 11.4 & 13.5 & 9.4 \\
\hline Credit to the government (net) & 1.5 & 4.1 & 1.9 & 0.4 & 1.8 \\
\hline Credit to the economy & 6.8 & 6.8 & 9.5 & 13.1 & 7.6 \\
\hline Other items (net) & -1.9 & -11.1 & -2.5 & -4.6 & -3.0 \\
\hline \multicolumn{6}{|l|}{ Memorandum items: } \\
\hline Velocity (GDP/M3) & 1.59 & 1.56 & 1.53 & 1.47 & 1.42 \\
\hline Multiplier (M3/M0) & 5.14 & 4.87 & 4.75 & 4.60 & 4.19 \\
\hline GDP & 37,767 & 41,408 & 45,629 & 50,325 & 53,727 \\
\hline Nominal GDP growth & 7.3 & 9.6 & 10.2 & 10.3 & 6.8 \\
\hline
\end{tabular}

Sources: Tunisian authorities; and Fund staff estimates and projections.

1/ M2 plus long term deposits. 
Table 5. Tunisia. Illustrative Medium-Term Growth Scenario, 2006-14

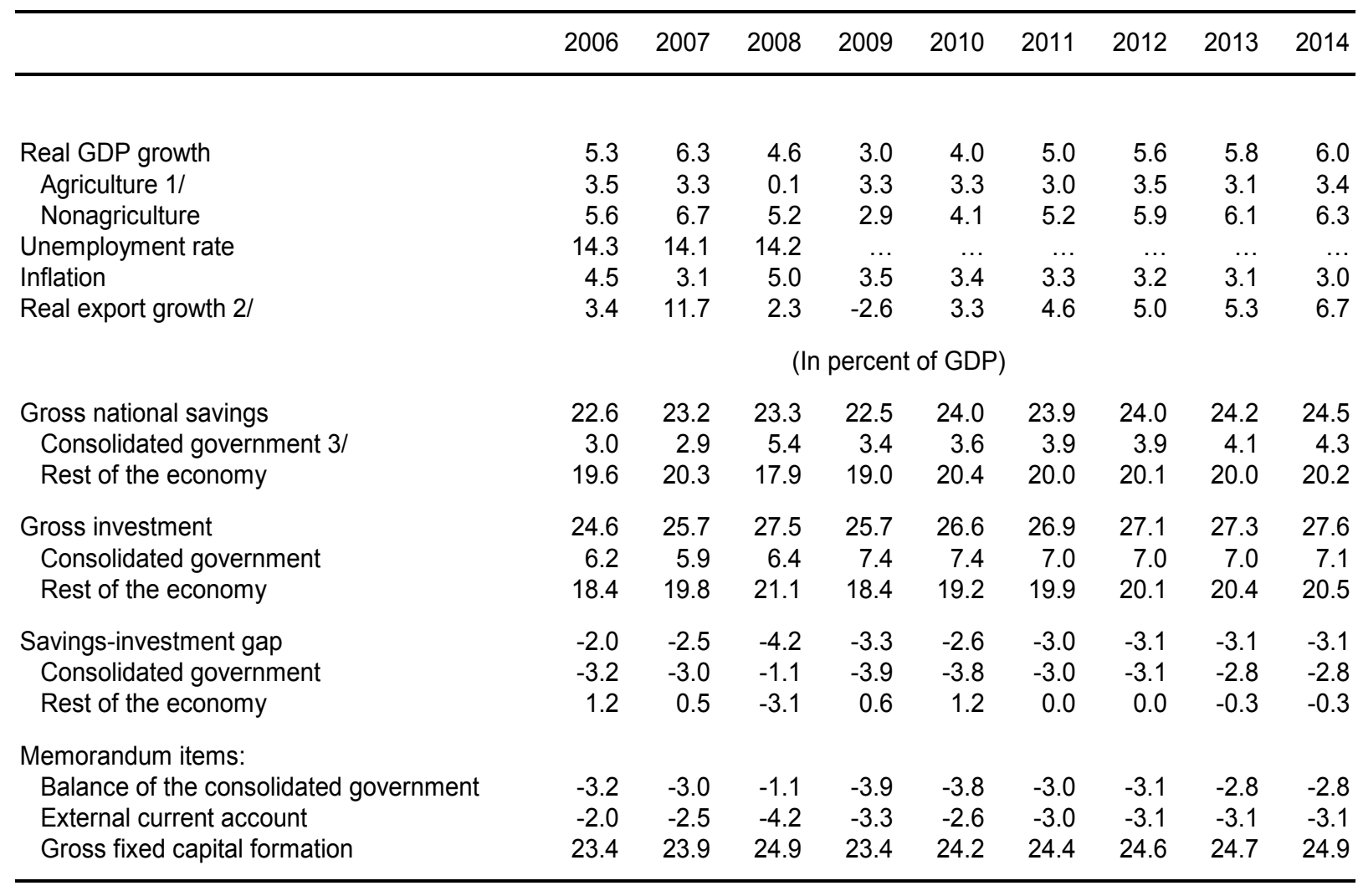

Sources: Tunisian authorities; and staff estimates.

1/ Based on average growth of agricultural output from 2001 onwards.

2/ Goods and nonfactor services.

3/ Includes social security, excludes privatization receipts. 
Table 6. Tunisia: External Debt Sustainability Framework, 2004-2014

(In percent of GDP, unless otherwise indicated)

\begin{tabular}{|c|c|c|c|c|c|c|c|c|c|c|c|c|}
\hline & \multicolumn{5}{|c|}{ Actual } & \multicolumn{7}{|c|}{ Projections } \\
\hline & 2004 & 2005 & 2006 & 2007 & 2008 & 2009 & 2010 & 2011 & 2012 & 2013 & 2014 & \multirow{3}{*}{$\begin{array}{c}\text { Debt-stabilizing } \\
\text { non-interest } \\
\text { current account 6/ }\end{array}$} \\
\hline & & & & & & & & & & & & \\
\hline Baseline: External debt & 66.5 & 65.3 & 58.1 & 53.9 & 53.7 & 52.5 & 52.3 & 50.5 & 48.9 & 47.2 & 45.8 & \\
\hline Change in external debt & -0.3 & -1.3 & -7.2 & -4.2 & -0.2 & -1.2 & -0.2 & -1.8 & -1.6 & -1.7 & -1.4 & \\
\hline Identified external debt-creating flows $(4+8+9)$ & -5.7 & 2.3 & -17.2 & -10.3 & -3.0 & -1.8 & -2.9 & -3.1 & -3.3 & -3.6 & -3.8 & \\
\hline Current account deficit, excluding interest payments & 0.4 & -1.4 & -0.2 & 0.4 & 2.6 & 1.6 & 1.2 & 1.7 & 1.9 & 1.9 & 2.0 & \\
\hline Deficit in balance of goods and services & 2.8 & 0.3 & 1.8 & 1.8 & 3.4 & 2.4 & 3.8 & 4.1 & 4.4 & 4.5 & 4.3 & \\
\hline Exports & 44.9 & 52.4 & 49.6 & 53.2 & 64.4 & 50.6 & 51.4 & 51.7 & 51.4 & 51.2 & 52.0 & \\
\hline Imports & 47.7 & 52.7 & 51.5 & 55.0 & 67.8 & 53.0 & 55.2 & 55.8 & 55.8 & 55.7 & 56.3 & \\
\hline Net non-debt creating capital inflows (negative) & -2.1 & -2.7 & -10.6 & -4.2 & -6.0 & -3.5 & -3.5 & -3.7 & -3.8 & -4.1 & -4.3 & \\
\hline Automatic debt dynamics $1 /$ & -4.0 & 6.4 & -6.4 & -6.5 & 0.4 & 0.1 & -0.6 & -1.1 & -1.4 & -1.4 & -1.5 & \\
\hline Contribution from nominal interest rate & 2.2 & 2.4 & 2.2 & 2.0 & 1.9 & 1.7 & 1.4 & 1.4 & 1.3 & 1.2 & 1.2 & \\
\hline Contribution from real GDP growth & -3.7 & -2.9 & -3.0 & -3.1 & -2.4 & -1.6 & -2.0 & -2.5 & -2.7 & -2.6 & -2.6 & \\
\hline Contribution from price and exchange rate changes $2 /$ & -2.5 & 6.8 & -5.6 & -5.3 & 1.0 & $\ldots$ & $\ldots$ & $\ldots$ & $\ldots$ & $\ldots$ & $\ldots$ & \\
\hline Residual, incl. change in gross foreign assets $(2-3) 3 /$ & 5.4 & -3.6 & 10.0 & 6.1 & 2.8 & 0.6 & 2.7 & 1.3 & 1.7 & 2.0 & 2.4 & \\
\hline External debt-to-exports ratio (in percent) & 148.3 & 124.6 & 117.0 & 101.3 & 83.4 & 103.7 & 101.7 & 97.7 & 95.0 & 92.2 & 88.1 & \\
\hline Gross external financing need (in billions of US dollars) $4 /$ & 5.5 & 5.1 & 6.0 & 6.2 & 7.1 & 7.2 & 6.7 & 7.6 & 8.0 & 8.4 & 9.0 & \\
\hline in percent of GDP & 18.9 & 18.4 & 18.8 & 16.5 & 18.6 & 18.4 & 16.5 & 17.8 & 17.5 & 17.2 & 17.2 & \\
\hline Scenario with key variables at their historical averages 5 & & & & & & 52.5 & 50.3 & 47.5 & 45.2 & 43.2 & 41.7 & -5.0 \\
\hline \multicolumn{13}{|l|}{ Key Macroeconomic Assumptions Underlying Baseline } \\
\hline Real GDP growth (in percent) & 6.0 & 4.1 & 5.3 & 6.3 & 4.6 & 3.0 & 4.0 & 5.0 & 5.6 & 5.8 & 6.0 & \\
\hline GDP deflator in US dollars (change in percent) & 3.9 & -9.3 & 9.4 & 10.1 & -1.8 & -1.3 & -0.4 & 1.0 & 1.0 & 1.0 & 1.2 & \\
\hline Nominal external interest rate (in percent) & 3.6 & 3.5 & 3.9 & 4.0 & 3.6 & 3.2 & 2.8 & 2.8 & 2.7 & 2.7 & 2.6 & \\
\hline Growth of exports (US dollar terms, in percent) & 21.5 & 10.2 & 9.2 & 25.5 & 24.4 & -20.1 & 5.2 & 6.5 & 6.2 & 6.3 & 9.0 & \\
\hline Growth of imports (US dollar terms, in percent) & 19.0 & 4.3 & 12.6 & 25.1 & 26.7 & -20.5 & 7.8 & 7.2 & 6.7 & 6.5 & 8.4 & \\
\hline Current account balance, excluding interest payments & -0.4 & 1.4 & 0.2 & -0.4 & -2.6 & -1.6 & -1.2 & -1.7 & -1.9 & -1.9 & -2.0 & \\
\hline Net non-debt creating capital inflows & 2.1 & 2.7 & 10.6 & 4.2 & 6.0 & 3.5 & 3.5 & 3.7 & 3.8 & 4.1 & 4.3 & \\
\hline
\end{tabular}

$1 /$ Derived as $[r-g-\rho(1+g)+\varepsilon \alpha(1+r)](1+g+\rho+g \rho)$ times previous period debt stock, with $r=$ nominal effective interest rate on external debt; $\rho=$ change in domestic GDP deflator in US dollar terms, $g=$ real GDP growth rate

$\varepsilon=$ nominal appreciation (increase in dollar value of domestic currency), and $\alpha=$ share of domestic-currency denominated debt in total external debt.

$2 /$ The contribution from price and exchange rate changes is defined as $[-\rho(1+g)+\varepsilon \alpha(1+r)](1+g+\rho+g \rho)$ times previous period debt stock. $\rho$ increases with an appreciating domestic currency $(\varepsilon>0)$ and rising inflation $($ based on GDP deflator). $3 /$ For projection, line includes the impact of price and exchange rate changes.

4/ Defined as current account deficit, plus amortization on medium- and long-term debt, plus short-term debt at end of previous period.

5/ The key variables include real GDP growth; nominal interest rate; dollar deflator growth; and both non-interest current account and non-debt inflows in percent of GDP.

6/ Long-run, constant balance that stabilizes the debt ratio assuming that key variables (real GDP growth, nominal interest rate, dollar deflator growth, and non-debt inflows in percent of GDP) remain at their levels

of the last projection year. 
Figure 1. Tunisia: External Debt Sustainability: Bound Tests 1/ (External debt in percent of GDP)

Baseline and historical scenarios

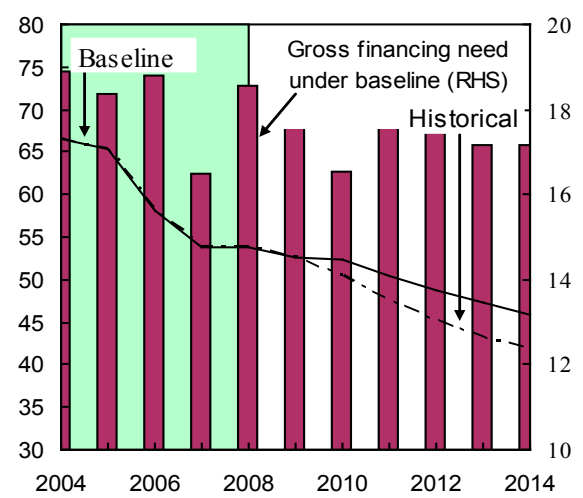

Growth shock (in percent per year)

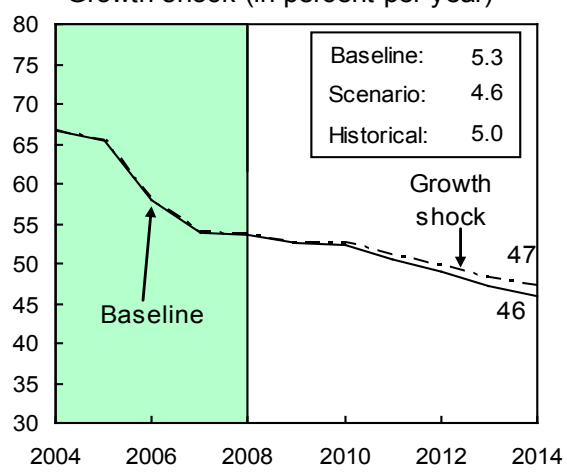

Combined shock 2/

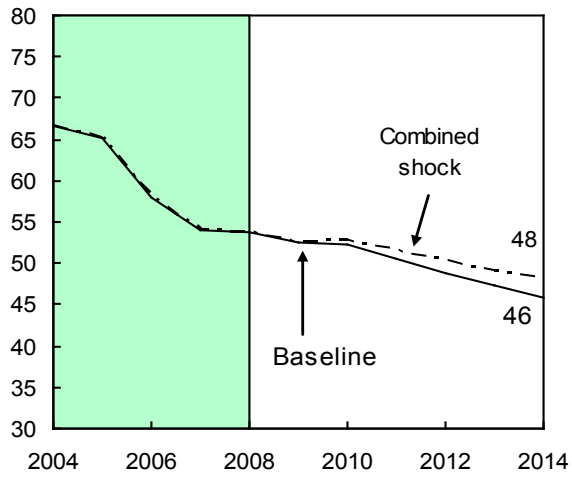

Interest rate shock (in percent)

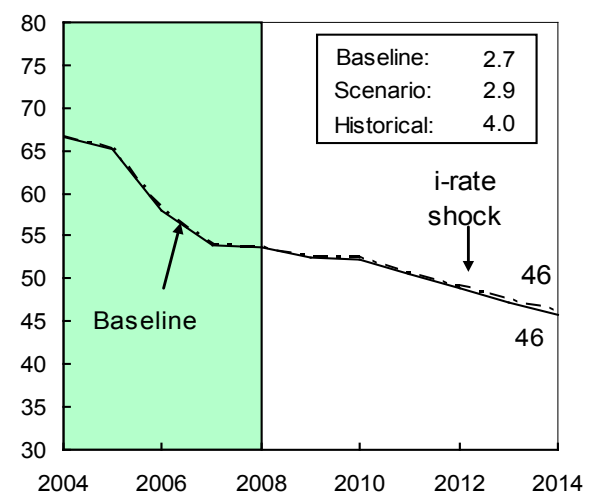

Non-interest current account shock (in percent of GDP)

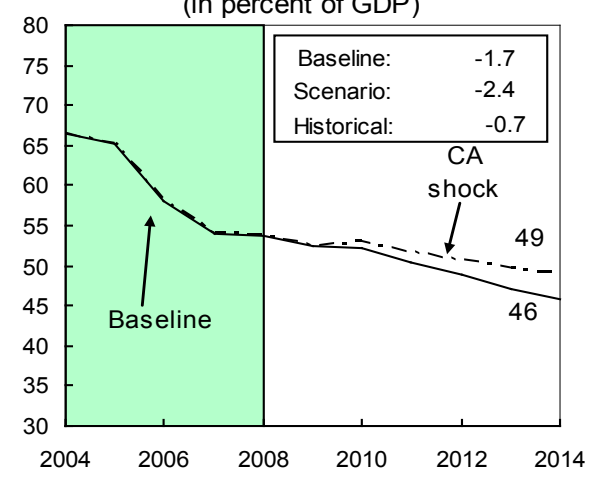

Real depreciation shock $3 /$

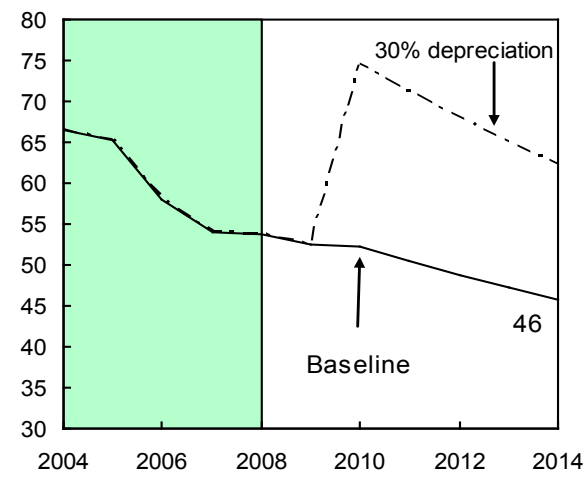

Sources: International Monetary Fund, Country desk data, and staff estimates.

$1 /$ Shaded areas represent actual data. Individual shocks are permanent one-half standard deviation shocks. Figures in the boxes represent average projections for the respective variables in the baseline and scenario being presented. Ten-year historical average for the variable is also shown.

2/ Permanent 1/4 standard deviation shocks applied to real interest rate, growth rate, and current account balance.

3/ One-time real depreciation of 30 percent occurs in 2009. 
Table 7. Tunisia: Public Sector Debt Sustainability Framework, 2004-14

(In percent of GDP, unless otherwise indicated)

\begin{tabular}{|c|c|c|c|c|c|c|c|c|c|c|c|c|c|}
\hline & & \multicolumn{5}{|c|}{ Actual } & \multicolumn{6}{|c|}{ Projections } & \multirow{3}{*}{$\begin{array}{c}\text { Debt-stabilizing } \\
\text { primary } \\
\text { balance } 9 /\end{array}$} \\
\hline & & 2004 & 2005 & 2006 & 2007 & 2008 & 2009 & 2010 & 2011 & 2012 & 2013 & 2014 & \\
\hline & & & & & & & & & & & & & \\
\hline Baseline: Public sector debt $1 /$ & 56.3 & 59.4 & 58.1 & 53.7 & 50.0 & 47.5 & 48.7 & 49.0 & 48.0 & 47.4 & 46.7 & 45.8 & -1.4 \\
\hline Of which: foreign-currency denominated & & 37.5 & 37.1 & 32.1 & 29.1 & 28.9 & 28.2 & 27.8 & 26.0 & 24.4 & 22.8 & 21.1 & \\
\hline Change in public sector debt & & -1.1 & -1.3 & -4.4 & -3.6 & -2.5 & 1.1 & 0.4 & -1.0 & -0.5 & -0.8 & -0.8 & \\
\hline Identified debt-creating flows $(4+7+12)$ & & -3.3 & 3.6 & -10.9 & -4.6 & -1.9 & 0.7 & 0.7 & -0.7 & -0.8 & -1.0 & -1.2 & \\
\hline Primary deficit & & -0.3 & 0.3 & 0.4 & 0.4 & -1.2 & 1.6 & 1.5 & 0.7 & 0.8 & 0.6 & 0.5 & \\
\hline Revenue and grants & & 29.8 & 29.4 & 29.4 & 30.0 & 32.6 & 30.3 & 29.6 & 29.5 & 29.2 & 29.2 & 29.0 & \\
\hline Primary (noninterest) expenditure & & 29.5 & 29.6 & 29.8 & 30.4 & 31.4 & 31.9 & 31.1 & 30.2 & 30.0 & 29.7 & 29.6 & \\
\hline Automatic debt dynamics $2 /$ & & -2.7 & 3.8 & -4.1 & -4.2 & -0.4 & -0.7 & -0.6 & -1.3 & -1.5 & -1.5 & -1.6 & \\
\hline Contribution from interest rate/growth differential $3 /$ & & -2.4 & -1.2 & -2.4 & -2.4 & -2.4 & -0.7 & -0.6 & -1.3 & -1.5 & -1.5 & -1.6 & \\
\hline Of which: contribution from real interest rate & & 1.0 & 1.0 & 0.5 & 0.7 & -0.3 & 0.6 & 1.2 & 1.0 & 1.0 & 1.1 & 1.0 & \\
\hline Of which: contribution from real GDP growth & & -3.3 & -2.3 & -2.8 & -3.1 & -2.1 & -1.3 & -1.8 & -2.3 & -2.5 & -2.5 & -2.6 & \\
\hline Contribution from exchange rate depreciation $4 /$ & & -0.3 & 5.0 & -1.7 & -1.8 & 2.0 & $\ldots$ & & & & $\ldots$ & $\ldots$ & \\
\hline Other identified debt-creating flows & & -0.4 & -0.4 & -7.2 & -0.9 & -0.3 & -0.2 & -0.2 & -0.2 & -0.1 & -0.1 & -0.1 & \\
\hline Privatization receipts (negative) & & -0.4 & -0.4 & -7.2 & -0.9 & -0.3 & -0.2 & -0.2 & -0.2 & -0.1 & -0.1 & -0.1 & \\
\hline Recognition of implicit or contingent liabilities & & 0.0 & 0.0 & 0.0 & 0.0 & 0.0 & 0.0 & 0.0 & 0.0 & 0.0 & 0.0 & 0.0 & \\
\hline Other (specify, e.g. bank recapitalization) & & 0.0 & 0.0 & 0.0 & 0.0 & 0.0 & 0.0 & 0.0 & 0.0 & 0.0 & 0.0 & 0.0 & \\
\hline Residual, including asset changes (2-3) 5/ & & 2.3 & -4.9 & 6.4 & 1.0 & -0.6 & 0.4 & -0.3 & -0.3 & 0.3 & 0.3 & 0.4 & \\
\hline Public sector debt-to-revenue ratio $1 /$ & & 199.2 & 198.0 & 182.8 & 166.9 & 145.6 & 160.3 & 165.9 & 162.7 & 162.4 & 160.0 & 157.8 & \\
\hline Gross financing need 6 / & & 6.0 & 6.0 & 7.4 & 6.2 & 2.7 & 6.2 & 5.7 & 5.8 & 5.5 & 4.9 & 4.9 & \\
\hline in billions of U.S. dollars & & 1.7 & 1.8 & 2.3 & 2.2 & 1.1 & 2.4 & 2.3 & 2.5 & 2.5 & 2.4 & 2.6 & \\
\hline Scenario with key variables at their historical averages 71 & & & & & & & 48.7 & 46.6 & 44.6 & 43.3 & 42.0 & 40.9 & -1.0 \\
\hline Scenario with no policy change (constant primary balance) in 2009-2014 & & & & & & & 48.7 & 50.7 & 50.5 & 50.7 & 50.9 & 51.0 & -1.5 \\
\hline \multicolumn{14}{|l|}{ Key Macroeconomic and Fiscal Assumptions Underlying Baseline } \\
\hline Real GDP growth (in percent) & & 6.0 & 4.1 & 5.3 & 6.3 & 4.6 & 3.0 & 4.0 & 5.0 & 5.6 & 5.8 & 6.0 & \\
\hline Average nominal interest rate on public debt (in percent) $8 /$ & & 5.1 & 5.1 & 5.1 & 5.3 & 5.0 & 5.2 & 5.0 & 5.1 & 5.0 & 5.1 & 5.2 & \\
\hline Average real interest rate (nominal rate minus change in GDP deflator, in percent) & & 1.9 & 2.0 & 1.1 & 1.7 & -0.4 & 1.5 & 2.7 & 2.2 & 2.4 & 2.6 & 2.4 & \\
\hline Nominal appreciation (increase in US dollar value of local currency, in percent) & & 0.7 & -12.0 & 5.1 & 6.3 & -6.8 & & & & & & & \\
\hline Inflation rate (GDP deflator, in percent) & & 3.2 & 3.1 & 4.1 & 3.6 & 5.4 & 3.7 & 2.3 & 2.8 & 2.6 & 2.6 & 2.8 & \\
\hline Growth of real primary spending (deflated by GDP deflator, in percent) & & 4.0 & 4.5 & 6.0 & 8.5 & 8.2 & 4.6 & 1.2 & 2.2 & 4.9 & 4.7 & 5.5 & \\
\hline Primary deficit & & -0.3 & 0.3 & 0.4 & 0.4 & -1.2 & 1.6 & 1.5 & 0.7 & 0.8 & 0.6 & 0.5 & \\
\hline
\end{tabular}

$1 /$ Indicate coverage of public sector, e.g., general government or nonfinancial public sector. Also whether net or gross debt is used.

2/ Derived as $[(r-\pi(1+g)-g+\alpha \varepsilon(1+r)] /(1+g+\pi+g \pi))$ times previous period debt ratio, with $r=$ interest rate; $\pi=$ growth rate of GDP deflator; $g=$ real GDP growth rate; $\alpha=$ share of foreign-currency

denominated debt; and $\varepsilon=$ nominal exchange rate depreciation (measured by increase in local currency value of U.S. dollar).

$3 /$ The real interest rate contribution is derived from the denominator in footnote $2 /$ as $r-\pi(1+g)$ and the real growth contribution as $-g$.

4/ The exchange rate contribution is derived from the numerator in footnote $2 /$ as $\alpha \varepsilon(1+r)$.

$5 /$ For projections, this line includes exchange rate changes.

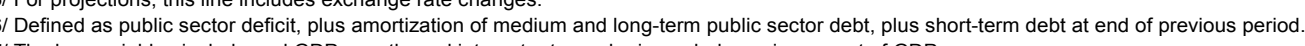

The key variables include real GDP growth, real interest rate; and primary balance in percent of GDP.

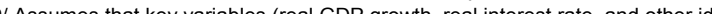


Figure 2. Tunisia: Public Debt Sustainability: Bound Tests 1/ (Public debt in percent of GDP)
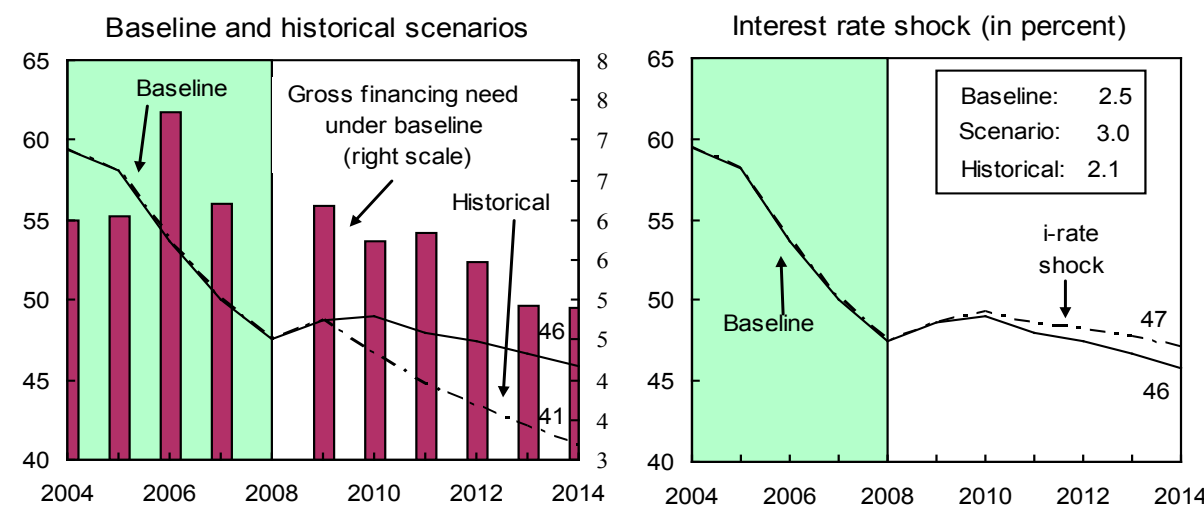

Growth shock (in percent per year)

Primary balance shock (in percent of GDP) and

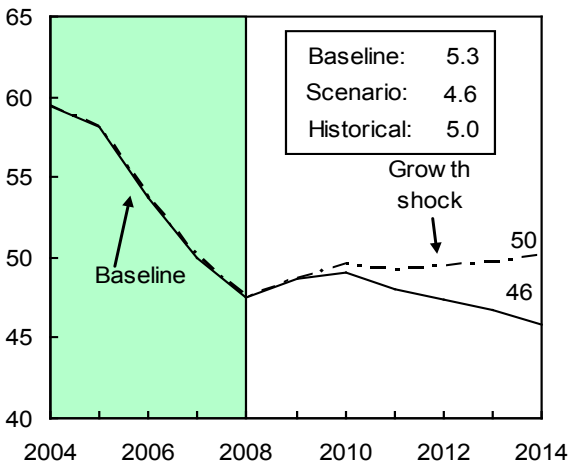
no policy change scenario (constant primary balance)

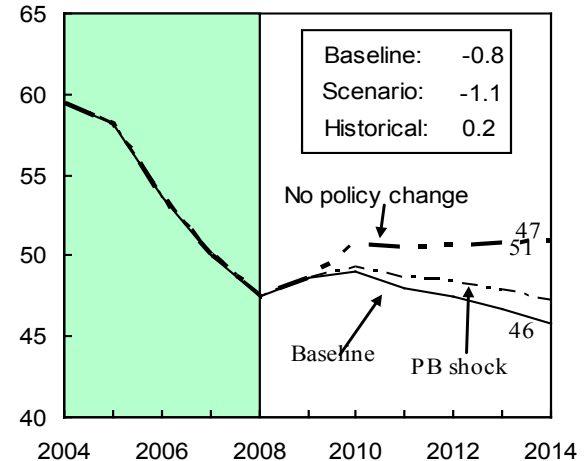

Combined shock 2/

Real depreciation and contingent liabilities shocks 3/
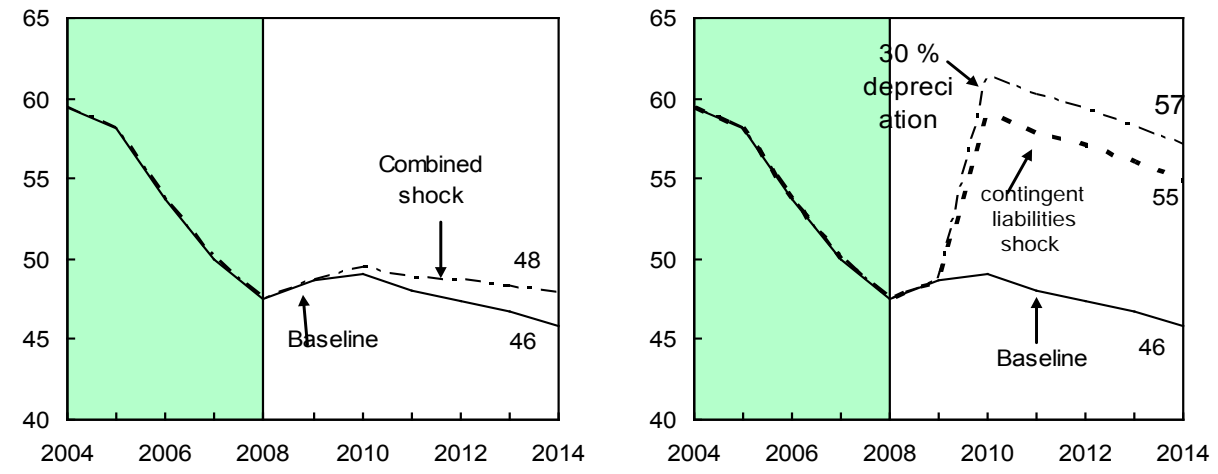

Sources: International Monetary Fund, country desk data, and staff estimates.

1/ Shaded areas represent actual data. Individual shocks are permanent one-half standard deviation shocks. Figures in the boxes represent average projections for the respective variables in the baseline and scenario being presented. Ten-year historical average for the variable is also show $\mathrm{n}$.

2/ Permanent 1/4 standard deviation shocks applied to real interest rate, grow th rate, and primary balance. 3/ One-time real depreciation of 30 percent and 10 percent of GDP shock to contingent liabilities occur in 2009, $w$ ith real depreciation defined as nominal depreciation (measured by percentage fall in dollar value of local currency) minus domestic inflation (based on GDP deflator). 
ANNEX I. TUNISIA: FUND RELATIONS

As of June 30, 2009

I. Membership Status: Joined: 04/14/1958; Article VIII

II. General Resources Account:

Quota

Fund Holdings of Currency

$\underline{\text { SDR Million }}$

\%Quota

286.50

100.00

Reserve position in Fund

266.27

92.94

20.25

7.07

III. SDR Department:

$\underline{\text { SDR Million }}$

\%Allocation

34.24

100.00

Holdings

3.31

9.66

IV. Outstanding Purchases and Loans:

None

V. Latest Financial Arrangements:

Approval Expiration Amount Approved Amount Drawn

\begin{tabular}{lcccc}
\multicolumn{1}{c}{ Type } & Date & Date & (SDR Million) & (SDR Million) \\
\hline EFF & $07 / 25 / 1988$ & $07 / 24 / 1992$ & 207.30 & 207.30 \\
Stand-by & $11 / 04 / 1986$ & $05 / 31 / 1988$ & 103.65 & 91.00
\end{tabular}

VI. Projected Obligations to Fund: (SDR Million; based on existing use of resources and present holdings of SDRs):

Forthcoming

\begin{tabular}{lccccr}
\hline & 2009 & 2010 & 2011 & 2012 & 2013 \\
\hline Principal & & & & & \\
Charges/Interest & 0.06 & 0.12 & 0.12 & 0.12 & 0.12 \\
Total & 0.02 & 0.12 & 0.12 & 0.12 & 0.12 \\
\hline
\end{tabular}




\section{Exchange Rate Arrangement and Exchange System}

Tunisia accepted the obligations of Article VIII Sections 2(a), 3, and 4 effective January 6, 1993, and maintains an exchange system that is free of restrictions on executing payments and transfers on current international transactions, except that Tunisia maintains (a) a multiple currency practice resulting from honoring exchange rate guarantees extended prior to August 1988 to development banks, which will automatically expire after maturity of existing commitments (total loans covered by these guarantees amount to about $\$ 20$ million); and (b) certain restrictions relating to Iraq and the Federal Republic of Yugoslavia (Serbia and Montenegro), pursuant to UN Security Council Resolutions, which are subject to notification to the Fund in accordance with Decision 144 (52/51).

Since March 1, 1994, the market rates are determined in an interbank foreign exchange market. On July 14, 2009, the interbank rate of the dinar vis-à-vis the dollar was \$1=TD 1.13392, equivalent to SDR 1= TD 2.0811.

\section{Article IV Consultation}

Tunisia is on the 12-month cycle. The last discussions of the Article IV consultation were held in Tunis from May 27 to June 9, 2008, and the consultation was concluded by the Executive Board on August 6, 2008.

\section{Technical Assistance}

January 31-February 14, 1996: FAD — assessment of revenue impact of Association Agreement with EU.

March 31-April 4, 1997: STA - introduction of new methodological guidelines according to fifth edition of Balance of Payments Manual.

September 9-12, 1998: MAE—monetary management and development of the money market.

May 11-21, 1999: STA—quarterly national accounts.

May 13-18, 1999: STA-SDDS.

October 12-15, 1999: MAE_-debt management practices.

October 17-27, 2000: STA—quarterly national accounts.

October 25-31, 2000; STA-SDDS meta data finalization.

December 17-21, 2001: MAE_-management of central bank liquidity.

December 12-19, 2003: LEG-AML/CFT. 
May 18-19, 2004: MFD — technical assistance needs assessment.

July 1-15, 2004: STA—government finance statistics. January 24-February 5, 2005: FAD-tax policy.

April 7-22, 2005: STA—ROSC, data module.

September 8-21, 2005: FAD-tax administration.

January 16-31, 2006: MFD—FSAP update (mission 1).

March 27-31, 2006: MFD_FSAP update (mission 2).

February 5-15, 2007: MCM—monetary policy.

February 4-7, 2008: LEG-AML/CFT supervisory training of the financial market supervision authority and the stock exchange.

Resident Representative: None 


\section{ANNEX II. TUNiSIA: WORLD BANK RELATIONS}

(As of July 1, 2009)

1. The World Bank's portfolio in Tunisia has a total of 17 active operations and 122 closed loans, of which 10 International Development Agency (IDA) credits amounting to $\$ 75.2$ million net of cancellations. Cumulative net commitments represent $\$ 5.6$ billion. Of this total, $\$ 4.3$ billion has been repaid. Net commitments for the 17 current operations amount to about $\$ 0.9$ billion.

2. The Country Assistance Strategy (CAS) was approved by the Board on June 3, 2004. It proposes to assist the Government of Tunisia in addressing three key challenges:

(a) strengthen the business environment to support the development of a more competitive, internationally integrated private sector and improve competitiveness of the Tunisian economy; (b) enhance skills and employability of graduates and labor force in a knowledge economy; and (c) improve the quality of social services through enhanced efficiency of public expenditures. The 2007 CAS progress report noted that, while the CAS is overall on track and remains fully relevant for Tunisia's key development challenges, the low level of domestic private investment constitutes a major concern, threatening growth and job creation. The new Country Partnership Strategy (CPS) is under preparation and is expected to be finalized before the end of 2009. The focus areas of the Bank's program will be (i) Employment, Growth and Competitiveness; (ii) Sustainable Development and Climate Change; and (iii) Quality of Service Delivery.

3. Bank lending is a mix of long-term investments in infrastructure and social sector financing, and development policy lending to support reforms at the sectoral and macroeconomic reforms. Recent loan includes the Integrated Competitiveness Development Policy Loan (\$250.0 million); the Water Sector Investment II Loan (\$30.6 million) and the Energy Efficiency Loan (\$55.0 million). The performance of investment projects continues to be satisfactory. However, procurement delays cause recurrent extension of closing dates.

4. The Bank's current portfolio has a strong focus on supporting economic reforms in trade integration, financial sector and private sector development and the Bank's partnership on trade, macroeconomic management and growth issues is excellent. The Bank is also heavily engaged in social sector issues with a focus on strengthening the quality of services in education and health. Challenges pertaining to climate change are being addressed by a variety of activities in natural resource management, water, energy, urban development and transport. Public Financial Management, Telecommunications, Rural Development and Cultural Heritage are also being supported.

5. Several Economic and Sector Work (ESW) and technical assistance (TA) outputs to inform and support policy choices and reforms were produced over the last two years. These include a study on global integration; Employment; Skills Development and Social 
Protection, Small and Medium Enterprise Study, Water Degradation; Wastewater Strategy, Use of Country Systems; and Health Management. Ongoing work includes a Development Policy Review; a Small and Medium Enterprise Finance Policy Note; a Review of Energy Management Policy; a Regional Study on the Constraints to Cross Border Investment and Trade in the Maghreb, Competitiveness Poles, Social Safety Nets, and Energy Markets in the Maghreb. The Bank is also supporting work on trade integration and agriculture trade policy, Budget Management and Performance Based Budgeting, Health Services, Urban Transport, Low-Carbon Transport Strategy and Labor Market Policies. 


\section{Tunisia: Financial Relations with the World Bank}

(As of July 1, 2009)

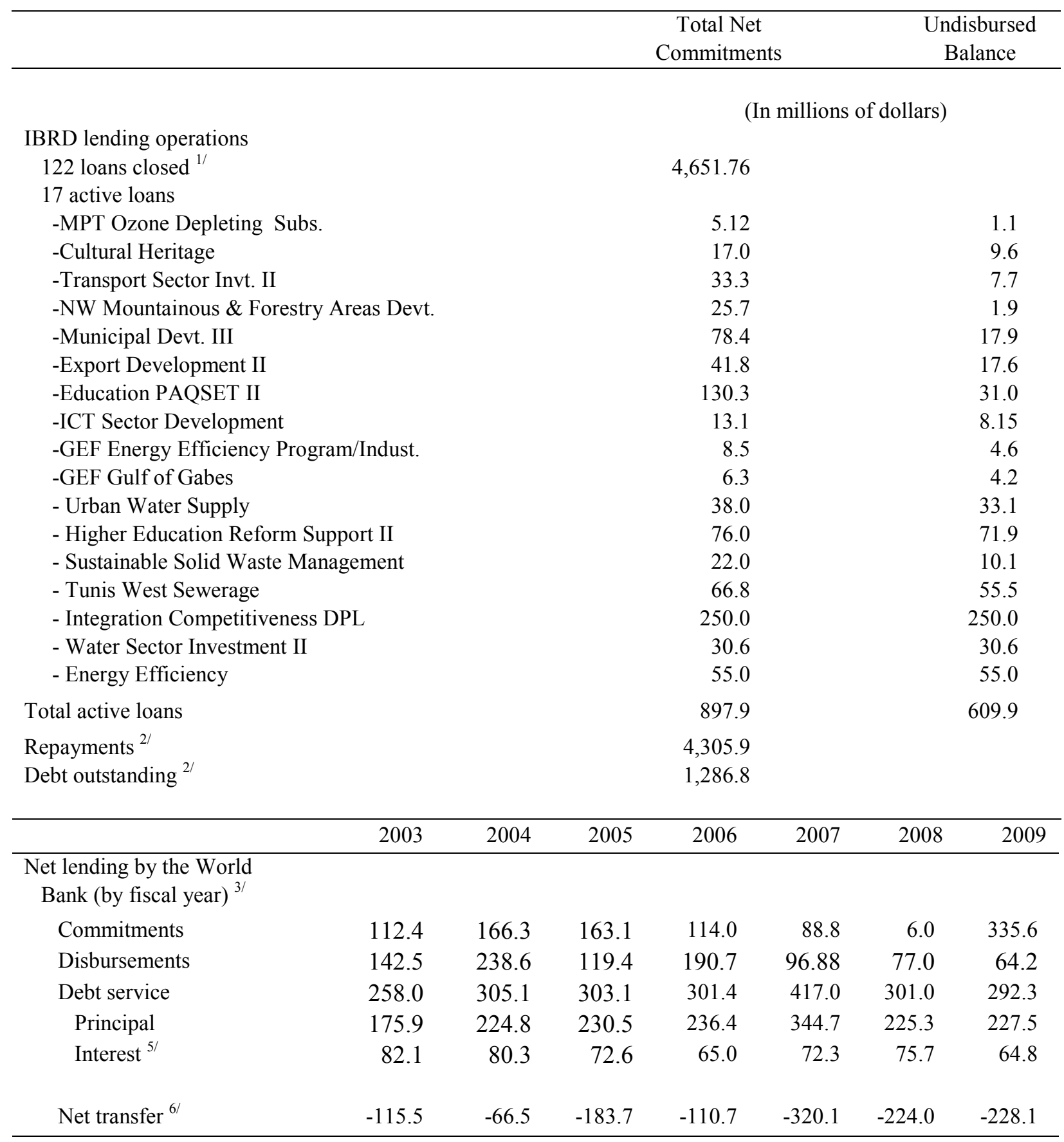

1/ Less cancellations, includes adjustment lending, does not include guarantees.

2/ As of July 1, 2008.

3/ Fiscal years start July 1 and end June 30 .

4/ Does not include \$184 million for guarantee on Jorf Lasfar electricity project.

$5 /$ Includes charges.

6/ Equal to disbursement minus debt service. 


\section{ANNEX III. TUNISIA: STATISTICAL ISSUES}

(as of July 15, 2009)

\section{Assessment of Data Adequacy for Surveillance}

General: Data provision is adequate for surveillance.

Real Sector Statistics: Currently disseminated quarterly real GDP estimates utilize a 1990 base year. Work to adopt the methodology of the 1993 System of National Accounts is advanced and will update the base year to the year 2000. Surveillance would benefit from the collection and dissemination of higher frequency data on employment, unemployment, and wages. Tunisia utilizes a periodicity and timeliness flexibility option for the labor market data category under the SDDS. Currently, annual employment and unemployment data are disseminated with a timeline of seven months.

External sector statistics: Are generally adequate for surveillance, although greater detail on the financial account would be desirable.

\section{Data Standards and Quality}

Subscribed to the Special Data Dissemination

Standard (SDDS) June 20, 2001.

A data ROSC was published on the IMF website on August 9, 2006.

\section{Reporting to STA (Optional)}

Data are being reported for publication in the International Financial Statistics (IFS), Government Finance Statistics Yearbook, the Direction of Trade Statistics, and the Balance of Payments Statistics Yearbook. 
Table of Common Indicators Required for Surveillance

As of July 15, 2009

\begin{tabular}{|c|c|c|c|c|c|c|c|}
\hline & Date of & & Frequency & Frequency & Freauency & Memo Items: & \\
\hline & $\begin{array}{c}\text { latest } \\
\text { observation }\end{array}$ & received & $\begin{array}{c}\text { of } \\
\text { Data }^{7}\end{array}$ & $\begin{array}{c}\text { of } \\
\text { Reporting }^{7}\end{array}$ & $\begin{array}{c}\text { of } \\
\text { Publication }\end{array}$ & $\begin{array}{l}\text { Data Quality - } \\
\text { Methodological } \\
\text { soundness }^{8}\end{array}$ & $\begin{array}{l}\text { Data Quality - } \\
\text { Accuracy and } \\
\text { reliability9 }\end{array}$ \\
\hline Exchange Rates & Current & Current & $\mathrm{D}$ & $\mathrm{D}$ & $\mathrm{D}$ & & \\
\hline $\begin{array}{l}\text { International Reserve Assets and } \\
\text { Reserve Liabilities of the Monetary } \\
\text { Authorities }^{1}\end{array}$ & June 2009 & Jul. 2009 & M & M & M & & \\
\hline Reserve/Base Money & May 2009 & $6 / 17 / 09$ & M & M & M & \multirow{4}{*}{$\mathrm{LO}, \mathrm{O}, \mathrm{LO}, \mathrm{LO}$} & \multirow{4}{*}{$\begin{array}{l}\text { LO, O, O, O, } \\
\text { LO }\end{array}$} \\
\hline Broad Money & May 2009 & $6 / 17 / 09$ & M & M & M & & \\
\hline Central Bank Balance Sheet & May 2009 & $6 / 17 / 09$ & M & M & M & & \\
\hline $\begin{array}{l}\text { Consolidated Balance Sheet of the } \\
\text { Banking System }\end{array}$ & May. 2009 & $6 / 17 / 09$ & M & Q & Q & & \\
\hline Interest Rates ${ }^{2}$ & Current & Current & $\mathrm{D}$ & $\mathrm{D}$ & $\mathrm{D}$ & & \\
\hline Consumer Price Index & June 2009 & $7 / 19 / 09$ & M & M & M & & \\
\hline $\begin{array}{l}\text { Revenue, Expenditure, Balance and } \\
\text { Composition of Financing }{ }^{3}- \\
\text { General Government }^{4}\end{array}$ & 2008 & Mar. 2009 & A & A & A & \multirow{2}{*}{ LO, LO, LO, O } & \multirow{2}{*}{$\begin{array}{l}\mathrm{O}, \mathrm{O}, \mathrm{O}, \mathrm{O} \\
\mathrm{LO}\end{array}$} \\
\hline $\begin{array}{l}\text { Revenue, Expenditure, Balance and } \\
\text { Composition of Financing }{ }^{3} \text { - Central } \\
\text { Government }\end{array}$ & Apr. 2009 & June 2009 & M & M & I & & \\
\hline $\begin{array}{l}\text { Stocks of Central Government and } \\
\text { Central Government-Guaranteed } \\
\text { Debt }^{5}\end{array}$ & Q4 2008 & Feb. 2009 & Q & Q & Q & & \\
\hline External Current Account Balance & Q1 2009 & May 2009 & Q & Q & Q & \multirow[b]{2}{*}{ LO, O, LO, LO } & \multirow{2}{*}{$\begin{array}{l}\mathrm{O}, \mathrm{O}, \mathrm{O}, \mathrm{O} \\
\quad \mathrm{LO}\end{array}$} \\
\hline $\begin{array}{l}\text { Exports and Imports of Goods and } \\
\text { Services }\end{array}$ & Q1 2009 & May 2009 & Q & Q & Q & & \\
\hline GDP/GNP & Q4 2008 & Apr. 2009 & Q & Q & Q & $\begin{array}{l}\text { LO, O, LNO, } \\
\text { LNO }\end{array}$ & $\begin{array}{l}\text { LO, O, LO, O, } \\
\text { LNO }\end{array}$ \\
\hline Gross External Debt & Q4 2008 & Mar. 2009 & A & A & A & & \\
\hline International Investment Position ${ }^{6}$ & 2008 & Jun. 2009 & A & A & M & & \\
\hline
\end{tabular}

${ }^{1}$ Any reserve assets that are pledged or otherwise encumbered should be specified separately. Also, data should comprise short-term liabilities linked to a foreign currency but settled by other means as well as the notional values of financial derivatives to pay and to receive foreign currency, including those linked to a foreign currency but settled by other means.

${ }^{2}$ Both market-based and officially determined, including discount rates, money market rates, rates on treasury bills, notes and bonds.

${ }^{3}$ Foreign, domestic bank, and domestic nonbank financing.

${ }^{4}$ The general government consists of the central government (budgetary funds, extra budgetary funds, and social security funds) and state and local governments.

${ }^{5}$ Including currency and maturity composition.

${ }^{6}$ Includes external gross financial asset and liability positions vis-à-vis nonresidents.

${ }^{7}$ Daily (D), weekly (W), monthly (M), quarterly (Q), annually (A), irregular (I); and not available (NA).

${ }^{8}$ Reflects the assessment provided in the data ROSC Substantive Update (published on August 9, 2006, and based on the findings of the mission that took place during April 7-22, 2005) for the dataset corresponding to the variable in each row. The assessment indicates whether international standards concerning concepts and definitions, scope, classification/sectorization, and basis for recording are fully observed (O); largely observed (LO); largely not observed (LNO); not observed (NO); and not available (NA).

${ }^{9}$ Same as footnote 7, except referring to international standards concerning (respectively) source data, assessment of source data, statistical techniques, assessment and validation of intermediate data and statistical outputs, and revision studies. 


\section{INTERNATIONAL MONETARY FUND}

EXTERNAL

\section{IMF Executive Board Concludes 2009 Article IV Consultation with Tunisia}

On September 1, 2009, the Executive Board of the International Monetary Fund (IMF) concluded the Article IV consultation with Tunisia on a lapse of time basis. ${ }^{1}$

\section{Background}

Sound economic policies and structural reforms underpinned by increasing trade openness allowed Tunisia to record higher growth in recent years and strengthen its footing to face the current global crisis. Tunisia enhanced its resilience with reduced public and external indebtedness and a largely improved reserves position. The Tunisian economy was relatively insulated from international financial contagion but is exposed to a slowdown in economic activity in its partner countries, particularly in Europe.

Although affected by the current crisis, Tunisia has weathered its impact relatively well so far. Real GDP growth slowed down from an average of 4.6 percent in 2008 to 0.5 percent in the first quarter of 2009, reflecting mainly a fall in exports of manufactured goods to EU countries. This drop was partially offset by buoyant growth in the mining and energy sectors and in some services. Domestic demand was sustained by investment and strong consumption fueled by salary increases. Inflation declined from an average of 5 percent in 2008 to 31/2 percent (yearon-year) in June 2009 due to the fall in global food and fuel prices and an appropriate monetary policy.

The current account deficit, after widening in 2008, contracted in the first quarter of 2009 thanks to lower import prices and resilient tourism and remittances receipts. Despite somewhat smaller

\footnotetext{
${ }^{1}$ Under Article IV of the IMF's Articles of Agreement, the IMF holds bilateral discussions with members, usually every year. A staff team visits the country, collects economic and financial information, and discusses with officials the country's economic developments and policies. On return to headquarters, the staff prepares a report, which forms the basis for discussion by the Executive Board. At the conclusion of the discussion, the Managing Director, as Chairman of the Board, summarizes the views of Executive Directors, and this summary is transmitted to the country's authorities. This year's Article IV consultation was concluded on a lapse of time basis. Under the IMF's lapse of time procedures, the Executive Board completes Article IV consultations without convening formal discussions. An explanation of any qualifiers used in summings up can be found here: http://www.imf.org/external/np/sec/misc/qualifiers.htm
} 
foreign investment inflows in early 2009, reserves reached US\$9 billion at end-May 2009 (5.6 months of projected imports).

The fiscal deficit declined markedly in 2008 to 1.2 percent of GDP and the public debt-to-GDP ratio was further reduced from 50 percent in 2007 to $471 / 2$ percent in 2008 . Revenue was boosted by buoyant customs duties levied on higher priced imports and strong corporate income tax receipts from high 2007 profits. Combined with lower interest payments, this more than offset expenditure overruns on subsidies for staple foods and petroleum products due to higher world prices.

Banks were not directly affected by the global financial crisis since they rely only slightly on external financing and their profitability increased in 2008, which contributed to a buoyant stock market. Credit to the economy further increased in the first quarter of 2009. Banks' soundness indicators continued to improve in 2008, but the level of non performing loans (NPLs) remains relatively high.

The authorities promptly deployed measures to contain the impact of the global crisis, including with the recently adopted fiscal stimulus package of about 1.4 percent of GDP and a more accommodating monetary policy by the Central Bank of Tunisia (BCT) in 2009, with the objective to reach a 3 percent real GDP growth this year. The medium-term outlook is favorable, based on the projected global economic recovery.

\section{Executive Board Assessment}

Executive Directors commended the authorities for the good performance of the Tunisian economy in the context of the global crisis, due to strong fundamentals resulting from sound policies implemented over the years. Directors considered that the growth outlook is favorable but that Tunisia still faces downside risks-pertaining to the transmission of the recession in Europe and the speed of impact of fiscal stimulus-and challenges related to the still high level of unemployment.

Directors supported the authorities' temporary expansionary fiscal stance to mitigate the impact of the global crisis and recommended that the fiscal stimulus be executed rapidly and have welltargeted expenditure in order to be most effective. They encouraged the authorities to consider extending the fiscal stimulus into 2010, given the still weak outlook anticipated in partner countries.

Directors welcomed the authorities' steadfast resolve to revert to fiscal consolidation once growth firms up and bring the public debt-to-GDP ratio back to a declining trend. They noted that a key pillar of the strategy should be the reduction in subsidies, through the continued effective implementation of the new oil price adjustment mechanism and improved targeting of measures to support the poorer segment of the population. They also supported a timely reform of the pension system to avoid a future burden on the budget. 
Directors considered that the BCT's monetary policy stance has been appropriate, with a cautious easing in 2009 to accommodate demand support. They recommended close coordination with fiscal policy and a gradual approach in further monetary easing, taking into consideration potential renewed inflationary pressures and risks of deteriorating prudential indicators of the banking system. They encouraged the authorities to continue implementing the building blocks for the planned inflation-targeting framework.

Directors noted that the exchange rate remains broadly aligned with its fundamentals and the authorities policies are consistent with external stability. They encouraged the authorities to continue anchoring the exchange rate policy to their medium-term objective of a freely floating exchange rate.

Directors observed that prudential indicators of the banking sector continued to improve but that the level of NPLs remains relatively high. They commended the authorities for implementing regulations that prevented the emergence of new NPLs, but encouraged them to make more resolute efforts to reduce the older stock in order to further strengthen the banking system's resilience, particularly given the gradual opening of the capital account. They recommended continued close monitoring of individual banks and supported the authorities' plans for further enhancing the quality of bank services.

Directors recommended that the regulatory and supervisory frameworks continue to adapt to financial sector developments. They favored a more forward looking approach to banking supervision, including in the context of future implementation of Basel II. They considered that systematic and comprehensive stress testing was needed to better assess the potential vulnerabilities of the banking system and to prepare appropriate contingency plans.

Directors congratulated the Tunisian authorities' for their pragmatic and steadfast approach to trade and financial integration, despite the currently adverse global environment. They noted that negotiations with the EU to extend the Association Agreement to services could become a key anchor for a gradual overhaul and liberalization of the services sectors and welcomed Tunisia's active participation in the regional integration effort. They recommended reducing the most-favored nation tariffs to prevent trade diversion and enhance geographic diversification. Directors welcomed continued improvement in the business climate through ongoing tax and customs administration reforms and programs supported by International Financial Institutions.

Public Information Notices (PINs) form part of the IMF's efforts to promote transparency of the IMF's views and analysis of economic developments and policies. With the consent of the country (or countries) concerned, PINs are issued after Executive Board discussions of Article IV consultations with member countries, of its surveillance of developments at the regional level, of post-program monitoring, and of ex post assessments of member countries with longer-term program engagements. PINs are also issued after Executive Board discussions of general policy matters, unless otherwise decided by the Executive Board in a particular case. 
Tunisia: Selected Economic Indicators, 2004-10

(Quota: SDR 286.5 million)

(Population: 10.3 million; 2008)

(Per capita GDP: \$3,632; 2008)

(Poverty rate: 3.8 percent; 2005)

(Main export: electronic and mechanical goods, textiles, energy, tourism; 2008)

\begin{tabular}{|c|c|c|c|c|c|c|c|}
\hline & 2004 & 2005 & 2006 & 2007 & $\frac{2008}{\text { Prel. }}$ & $\frac{2009}{\text { Proj. }}$ & $\frac{2010}{\text { Proj. }}$ \\
\hline \multicolumn{8}{|l|}{ Output and Prices } \\
\hline Real GDP (market price) & 6.0 & 4.1 & 5.3 & 6.3 & 4.6 & 3.0 & 4.0 \\
\hline Consumer prices (end of period) & 1.2 & 3.7 & 3.3 & 5.3 & 4.1 & 3.5 & 3.4 \\
\hline Consumer prices (period average) & 3.6 & 2.0 & 4.5 & 3.1 & 5.0 & 3.5 & 3.4 \\
\hline \multicolumn{8}{|l|}{ Investment and Saving } \\
\hline Gross capital formation & 24.5 & 22.3 & 24.6 & 25.7 & 27.5 & 25.7 & 26.6 \\
\hline Of which: Nongovernment $1 /$ & 17.5 & 15.9 & 18.4 & 19.8 & 21.1 & 18.4 & 19.2 \\
\hline Gross national savings & 21.8 & 21.3 & 22.6 & 23.2 & 23.3 & 22.5 & 24.0 \\
\hline Of which: Nongovernment $1 /$ & 17.3 & 18.0 & 19.6 & 20.3 & 17.9 & 19.0 & 20.4 \\
\hline \multicolumn{8}{|l|}{ Public Finances 2/ } \\
\hline Revenue, excluding grants and privatization & 23.8 & 23.6 & 23.4 & 23.8 & 26.2 & 23.7 & 23.3 \\
\hline Expenditure and net lending & 26.6 & 26.8 & 26.5 & 26.7 & 27.3 & 27.5 & 27.0 \\
\hline Budget balance, excluding grants and privatization & -2.8 & -3.2 & -3.0 & -2.9 & -1.2 & -3.8 & -3.8 \\
\hline Primary balance, excluding grants and privatization & 0.0 & -0.4 & -0.3 & -0.3 & 1.1 & -1.4 & -1.5 \\
\hline \multirow[t]{2}{*}{ Total government debt } & 59.4 & 58.1 & 53.7 & 50.0 & 47.5 & 48.7 & 49.0 \\
\hline & \multicolumn{7}{|c|}{ (Annual percentage change, unless otherwise indicated) } \\
\hline \multicolumn{8}{|l|}{ Monetary Sector } \\
\hline Credit to the economy & 5.3 & 6.3 & 6.6 & 9.7 & 13.5 & 8.0 & \\
\hline Base money & 12.2 & 21.9 & 17.6 & 15.3 & 17.6 & 21.8 & \\
\hline Broad money & 10.3 & 11.0 & 11.4 & 12.5 & 14.4 & 10.9 & \\
\hline Velocity of broad money & 1.6 & 1.6 & 1.6 & 1.5 & 1.5 & 1.4 & $\ldots$ \\
\hline \\
\hline in percent) $3 /$ & 5.1 & 5.1 & 5.1 & 5.1 & 5.1 & 4.0 & $\cdots$ \\
\hline & \multicolumn{7}{|c|}{ (In percent of GDP, unless otherwise indicated) } \\
\hline \multicolumn{8}{|l|}{ External Sector } \\
\hline Exports of goods (in US\$, percentage change) & 20.7 & 9.8 & 9.9 & 29.6 & 26.6 & -21.5 & 5.8 \\
\hline Imports of goods (in US\$, percentage change) & 18.3 & 3.4 & 12.8 & 26.9 & 28.7 & -21.4 & 8.2 \\
\hline Merchandise trade balance & -8.8 & -6.7 & -8.1 & -8.1 & -9.8 & -8.2 & -9.3 \\
\hline Current account excluding official transfers & -2.7 & -1.0 & -2.0 & -2.5 & -4.2 & -3.3 & -2.6 \\
\hline Current account including official transfers & -2.3 & -0.6 & -1.5 & -2.2 & -4.0 & -3.0 & -2.3 \\
\hline Foreign direct investment $4 /$ & 2.1 & 2.2 & 3.2 & 6.0 & 5.3 & 3.1 & 3.2 \\
\hline Total external debt $5 /$ & 66.5 & 65.3 & 58.1 & 53.9 & 53.7 & 52.5 & 52.3 \\
\hline Gross reserves (in billions of U.S. dollars) 6/ & 4.0 & 4.4 & 6.8 & 7.9 & 9.0 & 9.7 & 11.0 \\
\hline $\begin{array}{l}\text { In months of next year imports of goods and services } \\
\text { In percent of short-term external debt (on }\end{array}$ & 3.1 & 3.3 & 4.0 & 3.6 & 4.9 & 5.1 & 5.5 \\
\hline remaining maturity basis) & 82.2 & 88.3 & 136.7 & 146.4 & 150.3 & 171.2 & 173.7 \\
\hline \multicolumn{8}{|l|}{ Memorandum Items: } \\
\hline Nominal GDP (in US\$ billions) & 29.3 & 27.7 & 31.9 & 37.4 & 38.4 & 39.0 & 40.5 \\
\hline Unemployment rate (in percent) & 13.9 & 14.2 & 14.3 & 14.1 & 14.2 & $\ldots$ & $\ldots$ \\
\hline \multicolumn{8}{|l|}{ Net imports of petroleum products (in millions } \\
\hline of U.S. dollars) & 399.0 & 393.4 & 632.1 & -106.3 & 676.8 & -157.5 & -354.1 \\
\hline Terms of trade (deterioration -) & -4.4 & -2.3 & -3.6 & -1.9 & 1.0 & 3.9 & -2.1 \\
\hline Local currency per U.S. dollar (period average) & 1.2 & 1.3 & 1.3 & 1.3 & 1.2 & $\ldots$ & \\
\hline \multicolumn{8}{|l|}{ Real effective exchange rate (annual average, } \\
\hline percentage change) & -3.5 & -4.6 & -0.8 & -2.8 & -0.9 & $\cdots$ & \\
\hline Stock market index $7 /$ & $1,331.8$ & $1,615.1$ & $2,331.1$ & $2,614.1$ & $2,892.4$ & $3,589.4$ & $\ldots$ \\
\hline
\end{tabular}

Sources: Tunisian authorities; and IMF staff estimates.

$1 /$ Includes public enterprises.

$2 /$ The fiscal year is the calendar year.

$3 /$ In 2009, average for March.

4/ Excludes privatization receipts.

5/ Includes bank deposits of non-residents, most of whom in Tunisia for a long-term horizon, estimated at 7.7 percent

of GDP in 2008.

6/ Includes privatization receipts, which were about US\$2.2 billions in 2006 and averaged US\$0.1 billion in 2005 and 2007-08.

7/ TUNINDEX (1000=4/1/1998). The 2009 data as of July 13, 2009. 